\title{
The political economy of local government in Croatia: winning coalitions, corruption, and taxes
}

VUK VUKOVIĆ, Ph.D. candidate*

\author{
Article** \\ JEL: D72, D73, H71, D78, C21 \\ doi: $10.3326 /$ pse.41.4.1
}

\footnotetext{
* The author would like to thank to three anonymous referees for their valuable comments and suggestions.

${ }^{* *}$ Received: June 1, 2017

Accepted: October 20, 2017
}

The article was judged the best paper in the regular category in the annual competition for the Prof. Dr. Marijan Hanžeković Prize for 2017.

\section{Vuk VUKOVIĆ}

University of Oxford, Department of Politics and International Relations, Manor Road Building, Manor Road, Oxford OX1 3UQ, United Kingdom e-mail: vuk.vukovic@pmb.ox.ac.uk ORCiD: 0000-0001-7542-3006 


\section{Abstract}

This paper represents the first comprehensive effort to provide a theoretical and empirical explanation of systemic corruption in Croatian local government. It follows the logic of the selectorate theory, according to which staying in power for long periods of time depends on creating a small group of loyal but powerful supporters (the winning coalition). Mayors that exist within such environments not only maximize their chances of staying in power; they also engage in greater corruption and set higher taxes. Its citizens are stuck in a negative spiral of corruption, high taxes, and a politician that regardless of this keeps winning elections. The paper makes two main contributions to the current literature. First it provides a theoretical extension of the selectorate theory to Croatian local government by explicitly modeling the link between corruption and winning coalitions, and second, it empirically verifies the theoretical findings using a novel matching approach called entropy balancing.

Keywords: political economy, winning coalition, selectorate theory, corruption, taxes

\section{INTRODUCTION}

Corruption in Croatia is systemic, embedded deeply in the core of both national and local politics, and consequently of the domestic economy. Politicians holding power have developed and successfully maintained a crony system that helps them win office and reward their loyal cronies with exclusive deals and political protection. The result is a system where competitive advantage on the market is achieved mainly because of political connections instead of competence. Existing within such a crony microcosm enables a politician freely to extract rents, not having to worry about being punished by the voters.

The best way to illustrate this is with a few examples. Over the past two electoral cycles a number of mayors from major Croatian cities (Zagreb, Dubrovnik, Zadar, Varaždin, Vukovar, and the Sisak-Moslavina County) originating from both center-left and center-right political parties were arrested or indicted on corruption charges for abuse of power, bribery, and making favorable deals with selected private firms. They were either convicted or are still in trial. The Dubrovnik mayor was found guilty, served his sentence of six months of probation and then came back to win a local by-election in 2015 (Tomičić, 2015). The coalition government passed a special law in the months prior to the regular 2017 local election with the sole purpose of preventing him from running and most likely winning again (Romić, 2016). The mayor of Zagreb, in power for 16 years, after being arrested was immediately bailed out after paying the largest ever bail of 15 million kuna, arrested again for breaking his probation by intimidating witnesses, bailed out again after a few months thanks to a very quick Constitutional Court decision in his favor, and is still due to face trial on various charges (Petrušić, 2015). None of this prevented him from running in the parliamentary elections in 2015 (regular) and 2016 (repeated) with his new party, both times being elected as a member of 
parliament, or from winning a new four-year term as mayor in the 2017 local elections. For this entire period, even when he was in jail for six months, he was still the official mayor of Zagreb. These are just two of the most egregious cases that suggest there is something very wrong with how Croatian voters perceive corrupt politicians.

Why don't voters in Croatia punish their politicians for corruption? Many Croatian politicians have held their local offices for more than 20 years (the average tenure is over 10 years!). Have these politicians managed to design a system of key supporters so powerful and so efficient that even after being arrested or even convicted, they can still remain in power? Can political economy theory in any way explain these outcomes in which politicians in Croatia can stay in power for long periods of time with virtually no accountability to their voters? Who are they accountable to if not the voters?

This paper aims to provide both a theoretical and empirical explanation of systemic corruption in Croatian local government. The underlying theoretical logic of the paper is based on the selectorate theory from Bueno de Mesquita et al. $(2002,2005)$. The selectorate theory suggests that politicians can stay in power for long periods of time and simultaneously extract rents and shun any accountability if they create a powerful enough group of key supporters. This relationship provides mutual benefits to all players: the politicians stay in power while the supporters get direct benefits, either in favorable legislation, exclusive procurement contracts, jobs in the public sector, etc. (Shleifer and Vishny, 1994; Verdier, 1995; Root and Nellis, 2000; Faccio, 2006). Accordingly politicians are free to extract rents without hurting their election chances if they operate in small winning coalition environments within large electorates. In other words, the smaller the group of key supporters that delivers votes with respect to the entire electorate, the easier it is for a politician to bind the networks of key supporters to himself and hence maximize his chances of staying in power. Another unique prediction of the selectorate theory is that in small winning coalition environments a politician is free to impose higher taxes in order to fund the allocation of public resources towards private interests. Theoretical implications similar to those of the selectorate theory were given by North, Wallis and Weingeist (2009). They define such an environment as a typical limited access order in which institutions are personalized so that all political and economic outcomes depend on close interpersonal relationships between the ruling elites and various powerful groups that support them.

The empirical part of the paper proves the given theoretical predictions. It shows that Croatian systemic corruption can indeed best be explained by the selectorate theory, where longevity in office is dependent upon having small winning coalition environments and hence greater opportunities for corruption. Furthermore, mayors in small winning coalition cities or municipalities set higher local taxes. The greater the corruption of a mayor, the higher the tax rate he or she sets. Therefore, a mayor operating within a small winning coalition environment is likely to 
stay in power longer, be more corrupt, manipulate corruption to keep himself in office, and keep tax rates high. Lack of accountability in such environments will enable the mayor to get away with it, thus sending the entire community down a negative spiral of poor governance and loyal supporters of bad politicians.

The paper delivers two main contributions. First, it provides a theoretical extension of the Bueno de Mesquita et al. (2005) theory by establishing a direct link between the winning coalition and corruption. The selectorate theory accounts for this link indirectly, by explaining the motivation for higher corruption in small winning coalition systems. Leaders within small winning coalitions use corruption to reward their crony supporters, they use it to finance their own kleptocratic aspirations, and they discourage any attempt to reduce corruption as this strengthens the rule of law, thus weakening their hold on power. The theory therefore does predict a greater motivation for corruption, but it does not model it explicitly nor does it test empirically. This is the second contribution of the paper - its empirical verification of the theory and its main findings in the case of Croatia. It uses a direct proxy for corruption that confirms the motivation provided by the original selectorate theory.

In the following sections the paper first presents the underlying logic of the selectorate theory in section 2, after which it creates a new model in section 3 to explicitly define the relationship between winning coalition size and corruption. These two sections offer direct testable hypotheses for the empirical part of the paper. Section 4 lists the sources of data and describes the process of coding the main variables. Section 5 presents the empirical strategy and the subsequent results for each of the main theoretical implications. Section 6 concludes.

\section{THEORETICAL FRAMEWORK: SELECTORATE THEORY}

According to the selectorate theory, defined and introduced by Bueno de Mesquita et al. $(2002,2005)$, politicians win office and stay in power for long periods of time if they are integrated enough into the system, or in other words, if they create a powerful enough group of supporters/voters they can buy with various concessions, and which in return offer them persistent political support - the so called winning coalition $(\mathrm{W})$.

A winning coalition represents a group of voters essential for the politician to keep hold of power. This may include various influential organizations and interest groups such as unions, religious groups, civil society groups, entrepreneurs, or even the police and the army in autocratic regimes. A winning coalition is a subset of a larger group called the selectorate (S) representing all voters eligible to vote in a society. The smaller the winning coalition with respect to the size of the selectorate (the so-called W/S ratio), the greater the chances of political survival. This is due to the fact that members of small winning coalitions can easily be replaced by members outside of the coalition if they fail to remain loyal. The costs of defection of members within the winning coalition are too large (they lose their privi- 
leges and benefits). This testifies to a mutually dependent relationship between political elites and the groups they choose to include in their winning coalitions.

The main emphasis of the selectorate theory is to explain how the existence of a small coalition in a large electorate induces a lack of political accountability to the voters, which further leads to a lack of transparency in public decision making, the personalization of institutions, and the creation of clientelistic relationships that secure re-election. In environments with really small winning coalitions and large selectorates, like autocracies, politicians in power use private goods to satisfy their coalition members. In larger coalition environments, like democracies, politicians use public goods to satisfy a wide enough number of citizens for electoral support, which often implies an interconnection with corporate interests in the form of campaign donations and lobbying, and returning the favor via favorable legislation (McChesney, 1997; Grossman and Helpman, 2002; Faccio, 2006). The logic of political survival is the same in both systems; create a group of essential people powerful enough to secure reelection, and reward them with either direct monetary benefits, or indirect concessions.

Politicians in democracies can also use the support of so-called key members of the group within their winning coalitions. These are individuals who influence a large number of people and thus carry a greater weight in the electoral process. For example, politicians in democracies use the support of labor union leaders, which secures large amounts of votes by utilizing union membership. Politicians return the favor by rewarding the union leader, which effectively reduces the cost of maintaining the winning coalition. Despite the perception of a large coalition of voters who support them, they actually have a very small coalition made up of only a few key members. Other examples are military generals in autocracies, religious leaders, or even representatives of various ethnic groups, which in certain countries (or areas) are "worth" a significant number of votes.

Business interests can also influence the creation of small winning coalitions, where politicians reward entrepreneurs within the coalition by giving them exclusive government contracts via fraudulent public procurement procedures (Bandiera, Prat and Valletti, 2009; Ferraz and Finan, 2011). In return, the quasientrepreneurs, as key members of their own networks, use their influence to secure votes for the politicians. It is in the best interest of such corruptly-intralinked quasi-entrepreneurs for their politician to remain in power as long as possible (Verdier, 1995; Root and Nellis, 2000).

One of the main drawbacks of the selectorate theory is that its assumptions rest upon rational choice theory which assumes complete information and perfectly rational agents. This implies that not all of its theoretical findings will be supported in the data. In line with that critique Clarke and Stone (2008) find that its empirical results do suffer from an omitted variable bias, while Gallagher and Hanson (2015) find that the application of the theory to case studies is selective 
and that it fails to fully explain outcomes in autocratic regimes. Nevertheless, even though the theory is not a magic bullet for understanding democracies and dictatorships, it does offer an excellent framework for a testing ground.

An approach similar to the selectorate theory was developed by North, Wallis and Weingast (2009) through their theory of the institutional development of a society with respect to its response to violence. The authors define an institutional framework in which well-organized ruling elites can manipulate the economy by generating privileges based on the personalization of governing institutions. They call it a limited access order. In such systems the base of organization in a society is intrapersonal relationships between the powerful and the political elites, which successfully discourage the development of civil society and ensure long-term persistence of the constellation of political relationships. When the institutions of a system are depersonalized it is much harder to create clientelistic relationships. This is the case of an open access order, in which the foundation of intrapersonal interactions is a well-defined, depersonalized legal framework, and not politically generated privileges. Ivanković and Šonje (2011) use the framework set out in North et al. (2009) to define Croatia as a system of "undemocratic capitalism" in which institutions are personalized and there is a delicate balance of power between politics and politically-generated winners.

Croatia is therefore a good candidate for analysis under the selectorate theory framework, particularly its local government, in which mayors are allowed to stay in power indefinitely. In addition, the new electoral system imposed in 2009 redefined electoral rules to allow mayors to be elected directly (prior to 2009, voters voted for parties, where the mayor was usually the leader of the local party branch). This created some institutional limits for mayors, but it arguably gave them even more direct power than before.

Furthermore, Croatia is a country prone to corruption and budgetary misappropriation. It ranks among the five most corrupt EU member states (along with Greece, Italy, Bulgaria, and Romania) (European Commission, 2014), while Transparency International (2016) gives it an average score of 49 out of 100, making it a mostly corrupt country. There is ample research done in Croatia that confirms this. Bićanić (1997), Franičević (1997), Madžarević-Šujster and Mikulić (2002), Bejaković (2002), and Ott (2002) have all tried to measure and explain the extent of Croatia's grey economy and its systemic corruption. Štulhofer (2004) analyzes its impact on Croatia's depleting social capital and Budak and Rajh (2012) on the trust in the country's institutions. Bađun (2011) has shown a positive correlation between public investment spending and corruption, Ateljević and Budak (2010) successfully uncover corruption practices in domestic public procurement tenders, while Mačkić (2014) finds evidence of local political business cycles in Croatian cities that indicate opportunistic and rent-seeking behavior of politicians. Each of these research efforts painted an individual piece of the puzzle of why Croatia is so vulnerable to political distortions, poor institutions, corrup- 
tion, and lack of transparency. This paper aims to connect all the dots and provide an explanation rooted in the selectorate theory that can explain Croatia's persistently bad outcomes when it comes to dealing with bad politicians.

\section{MODEL}

One thing that is missing from the theoretical predictions of the selectorate theory is an explicit link between small winning coalitions and corruption. It confirms empirically that winning coalition size matters for taxation and political longevity in office but apart from justifying the motivation for corruption in kleptocratic regimes, it does not include a precise prediction on how winning coalition size is suppose to impact the potential corruption of politicians in power in democratic systems. This section combines the local government political alignment model of Brollo and Nannicini (2012) with the simple probabilistic voting model of Persson and Tabellini (2000) in order to make a theoretical extension to the selectorate theory.

The model starts by defining the incumbent mayor objective function. Politicians holding local power engage in corruption for two reasons: (1) to maximize their welfare (via obtaining rents), and (2) to maximize their probability of winning by buying the electoral support of key members of the winning coalition (Besley, 2006; Ferejohn, 1986; Brennan and Buchanan, 1980). The objective function of the mayor in power can then be defined as:

$$
W^{A}\left(r_{i}\right)=r_{i}+\operatorname{Pr}\left[V_{t}^{I} \geq \frac{1}{2}\right]+t y\left(r_{i}\right)
$$

Where $r_{i}$ represents total rents received by a politician $i$ during the entire term in office. The second term denotes the probability of winning for the politician (vote share $V_{t}^{I}$ for the incumbent $I$ in election year $t$ needs to be higher than $1 / 2$ to win). This is a probabilistic function that is further defined below. The final term represents a budget constraint, where $t$ denotes the local tax rate ${ }^{1}$, and $y\left(r_{i}\right)$ is total income, which is by definition a negative function of rents. This means that greater rent extraction will lower incomes of the population, encouraging a negative reaction from voters which lowers political utility. The budget constraint therefore represents the opportunity cost of rents.

Before performing the maximization of this objective function with respect to rents, we must first express the probability of winning for the local incumbent party as a function of vote share and rent-extraction. The vote share of the incumbent party can be expressed by:

$$
V_{t}^{I}=V_{t-1}^{I}-\frac{W}{S} r_{i}^{2}+\mu
$$

The first term $V_{t-1}^{I}$ is the vote share of the incumbent party in the previous election depicting the simple incumbency advantage (a typical implication of the political

\footnotetext{
${ }^{1}$ In Croatia this is the income tax surcharge rate (prirez) that is used to finance the local government.
} 
science literature, e.g. Gelman and King, 1991; Ansolabahere and Snyder, 2002; or Lee, 2008). The final term is a random stochastic shock $\varepsilon$ distributed normally on $\mu \sim\left[-\frac{1}{2 \sigma}, \frac{1}{2 \sigma}\right]$, and it represents all the possible factors that could influence electoral chances apart from rents (corruption) and the incumbency advantage (such as ideological preferences of the voters, specific politician idiosyncrasies, informational asymmetry, better campaign, more experience, etc.). The middle term represents a unique prediction of the selectorate theory (Bueno de Mesquita et al., 2005): negative rents squared (following the logic of concave rent-extraction, according to which too much in rents can reduce vote share at the election) multiplied by the ratio of the winning coalition (W) over the entire selectorate (S). The smaller the winning coalition with respect to the selectorate (i.e. for low levels of W/S), the greater the scope for corruption, and the higher the probability of winning. Small coalition environments are characterized by low levels of transparency and political accountability, and hence greater scope for corruption. On the other hand, in such environments it is much easier for an incumbent politician to gather a small winning coalition of key supporters, enough to keep him in power, whilst distributing budgetary funds both to them and himself. Therefore in equation (2) a small $\mathrm{W} / \mathrm{S}$ ratio will imply a lower punishment for corruption, whereas a large $\mathrm{W} / \mathrm{S}$ ratio implies greater punishment, reducing the incentives for corruption. We should observe higher corruption in small winning coalition environments, and lower corruption in large winning coalition environments.

The probability of winning for the mayor is the probability that more than half of the electorate ${ }^{2}$ votes for him; $V_{t}^{I} \geq \frac{1}{2}$.

$$
\begin{gathered}
P_{w}^{I}=\operatorname{Pr}\left[V_{t}^{I} \geq \frac{1}{2}\right] \\
=\operatorname{Pr}\left[V_{t-1}^{I}-\frac{W}{S} r_{i}^{2}+\mu \geq \frac{1}{2}\right]
\end{gathered}
$$

Given that this is a probabilistic voting function based on Persson and Tabellini (2000), the winning probability becomes a particular point on the cumulative distribution function of $\mu$ :

$$
\begin{aligned}
& =\operatorname{Pr}\left[\mu \geq \frac{1}{2}-V_{t-1}^{I}+\frac{W}{S} r_{i}^{2}\right] \\
& =1-\frac{\left[\frac{1}{2}-V_{t-1}^{I}+\frac{W}{S} r_{i}^{2}\right]+\frac{1}{2 \sigma}}{\frac{1}{\sigma}}
\end{aligned}
$$

\footnotetext{
${ }^{2}$ In reality, with multiple party races it takes much less than $50 \%$ of the electoral vote to win. A random parameter could have been used instead of the $1 / 2$ threshold, however this would not have changed the theoretical prediction.
} 
Which yields the following probabilistic function continuous in $r_{i}$ :

$$
\operatorname{Pr}\left[V_{t}^{I} \geq \frac{1}{2}\right]=\frac{1}{2}-\sigma\left(\frac{1}{2}-V_{t-1}^{I}+\frac{W}{S} r_{i}^{2}\right)
$$

We can now insert this into the government objective function from equation (1), and formulate the following maximization problem of the incumbent:

$$
\max _{r_{i}}\left[r_{i}+\frac{1}{2}-\sigma\left(\frac{1}{2}-V_{t-1}^{I}+\frac{W}{S} r_{i}^{2}\right)+t y\left(r_{i}\right)\right]
$$

The first order condition is:

$$
1-2 \sigma \frac{W}{S} r_{i}+t y^{\prime}\left(r_{i}\right)=0
$$

For which we get:

$$
r_{i}=\frac{t y^{\prime}\left(r_{i}\right)+1}{2 \sigma \frac{W}{S}}
$$

which holds if $\sigma \neq 0, \forall \sigma \in<0,1>$, and if $W, S>0$. Total rents can therefore be expressed as a function of the opportunity cost of rents, the W/S ratio, and the distribution of the asymmetric shock, $\sigma$. According to equation (10), rents increase when the winning coalition is small $W \lim 0$, adhering to the logic of the selectorate theory, and when asymmetric shocks are large $\sigma \underline{\lim } 0$. The distribution of $\varepsilon \sim u\left[-\frac{1}{2 \sigma}, \frac{1}{2 \sigma}\right]$ implies that a $\sigma$ value approaching 0 entails a wide shock, which could mean a greater difference in political abilities of candidates, a high level of informational asymmetry (lack of transparency), or high levels of ideological uniformity which also induces lack of transparency and hence encourages rent-extraction. The implication is that, for example, with large differences in ideology between the incumbent and the challenger in an ideologically uniform city or municipality, mayors can get away with corrupt activities more easily. The empirical section approximates $\sigma$ as political polarization which measures ideological uniformity of a city or municipality.

The model allows us to draw several important empirical implications from this extension to the selectorate theory. The first is that a small W/S ratio is good for rents, meaning that we should observe greater corruption in small winning coalition environments. In addition, higher levels of political polarization, higher local taxes, and greater total income should all increase the scope for corruption. This is explicitly tested and proven in the empirical section. Second, the selectorate theory itself implies that small winning coalition environments are supposed to result in higher taxes and longer years in power of an incumbent politician. This too, although not modeled, is explicitly tested for and proven in the empirical part of the paper. 
The dataset comprises several main variables: the W/S ratio, proxy for corruption, local income tax surcharge rates, political re-election, and total years in power. This section describes the data sources as well as the operationalization of each variable (a table of all variables used, summarizing their definitions and sources is available in the appendix).

The main independent variable in testing each theoretical hypothesis is the $W / S$ ratio: the winning coalition divided by the entire selectorate. While measuring the size of the selectorate $(\mathrm{S})$ is rather straightforward (total number of eligible voters), measuring the winning coalition requires some approximation. One way of doing so would be to look at the absolute number of voters who voted for the incumbent mayor. Defining a winning coalition (W) this way does not necessarily include only politically-connected voters, but it does show how many voters the incumbent managed to attract, some of whom were certainly politically connected. In other words the absolute number of voters who voted for the incumbent includes a subset of politically-connected voters, but not every vote for the mayor came from his loyal cronies. Bueno de Mesquita et al. (2005) approximate the winning coalition in a similar way, particularly in cases of democratic countries. The $W / S$ ratio therefore captures the ratio of votes for the incumbent candidate over the total number of eligible voters in a local unit. It is a continuous variable with a mean of 0.27 and standard deviation of 0.1 . The mean value of 0.27 is a good representation of what the W/S ratio actually stands for, as it implies that an incumbent needs only $27 \%$ of those eligible to vote to cast their vote for him or her to win a local unit. This means that, on average, politicians have a rather low voter base they need to satisfy in order to win. For example, the minimum value of $3.4 \%$ is a particularly worrisome number, given that politicians in this city or municipality can easily manipulate a small subset of voters into their winning coalitions. The point of the ratio is therefore to show how likely it is for a crucial group of politically-connected voters to generate more clout in local low-turnout environments.

In addition to taking the $\mathrm{W} / \mathrm{S}$ ratio at face value it makes sense to separate it based on its median value $(0.26)$ in order to distinguish between large and small W/S environments, and thus code them as an indicator as well (W/S_binary). The median is taken so as to generate a binary indicator with exactly one half of all cities and municipalities on either side of the cutoff. This will be used as a robustness check of the validity of the indicator.

Corruption in itself is very difficult to measure, primarily since anyone engaged in corrupt activities has every incentive to hide them. The proxy for corruption was taken from Vuković (2017) at the level of 556 cities and municipalities in Croatia. The original source of this data was the Official Gazette of the Republic of Croatia, and its registry of public procurement. It contained more than 35,000 contracts signed during a single term in local office, from 2009 to 2013. The total value of 
all contracts was 28,765 billion kuna. Each corruption proxy was created as the ratio of suspicious procurement contracts to total procurement contracts in a given city or municipality for the entire 4-year period.

The definition of a suspicious procurement entails several different categories. The main three characteristics of a corrupt procurement include:

- cases in which firms with zero employees won multiple public tenders (fake firms),

- cases in which the value of the procurement contracts exceeds the annual average revenues of a firm (several categories are used), and

- cases in which the value of the contract is being given to firms with losses, where the contract covers the entire loss and enables the firm to operate at a profit in the following year.

In this paper only the total index of corruption for each city or municipality was used, which is the weighted average of all previous categories of corruption (and their extrapolations), designed carefully so as not to include the same value more than once (labeled Corruption Index). The total index thus represents the finite level of corruption in each local unit, accounting for all potential frauds.

It should be noted however that this index does not measure corruption directly (given that this is impossible without data on criminal investigations and court rulings), but it only offers an approximation of corruption, where any case of potentially fraudulent procurement offers a reasonable doubt as to the validity of the procedure of assigning the contract. Further justification of the usage of this index can be found in Vuković (2017), who cites interviews with local government and law enforcement officials, public sector bureaucrats, and entrepreneurs in legitimizing the usage of the aforementioned characteristics in describing potential corruption.

The next set of data was local electoral results. These were taken from the State Electoral Commission of the Republic of Croatia (DIP, 2014) for the following elections for all 556 Croatian cities and municipalities: local elections in 2009 and 2013, and parliamentary elections in 2011. The variables for political use were taken from Glaurdić and Vuković $(2016,2017)$. These include a number of political and mayoral characteristics: turnout in the 2013 local election (Turnout), vote share of parties and candidates received in the 2011 national election (HDZ and $S D P$ vote share), political experience (Years in power), political polarization (EPI), size of governing coalition in 2009 (Size of gov coalition), mayor majority in 2009 (Mayor majority), size of local assembly (Assembly size), an indicator of whether the mayor was from the same party that held national power (Mayor gov), and an indicator variable of re-election (Re-election). A few of these require further clarification. The indicator of re-election assigns the value of 1 if a local mayor was re-elected or, in cases where the mayor retired or left for higher office, when his or her party remained in power. A value of 0 is assigned in all other 
cases. Political polarization was measured as an index of vote share between two major political blocs ${ }^{3}$; the left and the right, within a given local unit. The larger the index the greater the difference between the two electoral blocs (the more ideologically uniform a local unit), whereas a small difference depicts ideologically divided municipalities with strong support for either the left or the right.

\section{TABLE 1}

Summary statistics

\begin{tabular}{|c|c|c|c|c|c|}
\hline Variable & Observations & Mean & Std. dev. & Min. & Max. \\
\hline $\mathrm{W} / \mathrm{S}$ ratio & 546 & 0.270 & 0.102 & 0.034 & 0.681 \\
\hline W/S_binary & 546 & 0.469 & 0.499 & 0 & 1 \\
\hline Corruption Index & 546 & 0.083 & 0.127 & 0 & 0.75 \\
\hline Tax rate (prirez) & 546 & 0.042 & 0.043 & 0 & 0.18 \\
\hline Re-election & 546 & 0.731 & 0.444 & 0 & 1 \\
\hline Years in power & 546 & 8.668 & 3.532 & 2 & 12 \\
\hline Turnout & 546 & 0.478 & 0.100 & 0.231 & 0.886 \\
\hline HDZ vote share & 546 & 0.206 & 0.115 & 0.003 & 0.675 \\
\hline SDP vote share & 546 & 0.244 & 0.098 & 0.019 & 0.523 \\
\hline Mayor gov & 546 & 0.676 & 0.468 & 0 & 1 \\
\hline Size of gov coalition & 546 & 2.170 & 1.136 & 1 & 7 \\
\hline Mayor majority & 545 & 0.585 & 0.112 & 0.231 & 1 \\
\hline EPI & 546 & 0.818 & 0.177 & 0 & 0.996 \\
\hline Unemployment & 546 & 0.193 & 0.093 & 0.04 & 0.567 \\
\hline Income per capita & 546 & $1,696.8$ & 438.5 & 519.9 & $2,973.6$ \\
\hline Grants per capita & 546 & 507.3 & 998.5 & 0 & $11,575.9$ \\
\hline Croats & 546 & 0.889 & 0.172 & 0.018 & 1 \\
\hline Average age & 546 & 42.642 & 3.330 & 33.1 & 63.3 \\
\hline Years of education & 546 & 9.842 & 0.875 & 5.925 & 12.132 \\
\hline War disabled per 1,000 & 546 & 8.539 & 8.082 & 0 & 64.98 \\
\hline Settlement size & 546 & 3.006 & 0.545 & 1.65 & 5.78 \\
\hline Assembly size & 546 & 13.385 & 3.897 & 7 & 51 \\
\hline
\end{tabular}

Note: The data was collected for all 556 municipalities but 10 of them had no procurements in the given years so they were excluded from the dataset. Including them as a zero value does not influence the findings.

Sources: See appendix.

The size of governing coalition includes all parties which were a part of the local governing coalition (varying from 1 where only 1 party was holding local office to 7 where it took the coalition of 7 parties to get a legislative majority). This is not to be confused with the winning coalition, which is a more complex variable.

\footnotetext{
${ }^{3}$ The index is calculated using the following formula, adapted from Glaurdić and Vuković (2017) and originally proposed by Reynal-Querol's (2002) ethnic polarization index: $E P I=1-\sum_{i=1}^{N}\left(\frac{1 / 2-\pi_{i}}{1 / 2}\right)^{2} \pi_{i}$, where $\pi_{i}$ represents the proportion of votes given to three political blocs: the conservative bloc led by the HDZ containing all parties that classify as right-wing, the social-democrat bloc led by SDP containing all parties that classify as left-wing, and a few unaffiliated parties and independent candidates. This variable measures to which extent party competition within a city or municipality was polarized between the two main left and right blocs.
} 
The size of the local assembly is measured by the number of local councilmen in each local legislature (varying based on population size from 7 to 51 for the capital Zagreb). The mayor majority measures the proportion of deputies in the local council that support the mayor. Each of these variables is supposed to capture how difficult it was for the mayor to govern. Even though after 2009 the change in the law gave local mayors more authority as they were being elected directly, having a majority in the legislative assembly was still important for a mayor to pass the local budget.

Economic and demographic variables were taken from the Croatian Bureau of Statistics (CBS, 2011; 2013), the Croatian Unemployment Bureau (HZZ, 2014), and the Ministry of Finance (2014). These include data on local income tax surcharge rates (Tax rate - Prirez), total unemployment (Unemployment), total intergovernmental grants received by the local government, which are used to alleviate fiscal inequalities in municipalities (Grants $\mathrm{p} / \mathrm{c}$ ), incomes per capita (Income $\mathrm{p} / \mathrm{c}$ ), average number of Croats (Croats), average age (Average age), total years of education (Years of education), relative population size of a city or municipality (Settlement size) and total number of war-disabled as a proxy for casualties of the 1991-1995 Croatian Homeland War (War disabled). All the data are taken on the unit of cities and municipalities. Table 1 shows the summary statistics of each variable used.

\section{EMPIRICAL ANALYSIS}

\subsection{EMPIRICAL STRATEGY}

As stated in the theoretical section and derived from the model, there are three predicted effects of small winning coalition environments: (i) greater chances of political survival, (ii) higher levels of corruption, and (iii) higher tax rates. This section directly tests the given implications using several methodological approaches. It is important to note that the availability of data has limited the usage of time series-based approaches given that corruption data were only available during a single term of office, from 2009 to 2013. This means that the dataset at hand is a cross-section where levels of corruption are observed as a single time unit over the duration of the local mandate. This has forced the usage of all other independent variables as a single time point, in most cases taking 4-year averages, as well as looking at the value of political indicators in the 2009 elections.

In order to prove the theoretical predictions, the first step of the empirical analysis is to examine the impact of small winning coalition environments on political tenure and chances of political survival. The following equation takes political longevity in office (Years in power, $T_{i}$ ) as the dependent variable and the $\mathrm{W} / \mathrm{S}$ ratio as the main independent variable:

$$
T_{i}=\rho W S_{i}+\boldsymbol{X}_{\boldsymbol{i}} \boldsymbol{\gamma}+\mu_{i}
$$


Where $\boldsymbol{X}_{\boldsymbol{i}}$ is a vector of all political, economic, and municipality-specific controls for city or municipality $i$. Political controls include the level of political polarization in a local unit $(E P I)$, the relative size of the mayor's majority in terms of deputy support (Mayor majority), the size of the mayor's governing coalition (Size of gov coalition), an indicator variable of whether the mayor was from the party that held national power (Mayor gov), and the corresponding vote shares of HDZ and SDP in the national election in 2011 to control for change in relative party positions on a national level (HDZ and SDP vote share). Economic controls include average Unemployment during the term, average Income per capita, and average Grants per capita received from the central government. Finally the unit-specific controls include for each city and municipality the total percentage of Croats, Average age, total Years of education, number of War disabled per local unit, local Assembly size and the average size of the city or municipality (Settlement size).

The second step is to test the relationship between winning coalitions and corruption. A similar equation is estimated, where the $\mathrm{W} / \mathrm{S}$ ratio is again the main independent variable, while the dependent variable is the total index of corruption per city or municipality $i$ (Corruption index, $k_{i}$ ), featuring the same control variables as before:

$$
k_{i}=\rho W S_{i}+X_{i} \gamma+\mu_{i}
$$

Additionally, following the conclusions from Vuković (2017) which shows that corruption entails a concave effect on chances of re-election, meaning that voters reward corrupt behavior up until a certain level after which they do in fact punish corruption, the same relationship is tested here, but with respect to varying levels of the W/S ratio. It takes corruption and the squared value of corruption as the main independent variables regressing them against the indicator variable of re-election:

$$
P\left(R_{i}=1 \mid k_{i}\right)=\beta_{1} k_{i}+\beta_{2} k_{i}^{2}+\boldsymbol{X}_{i} \boldsymbol{\gamma}+\mu_{i}
$$

The same controls are used as before, however the sample is split into small and large winning coalition environments based on $W / S$ binary and the equation is estimated for each environment. This way it was possible to draw conclusions from two sets of environments: how corruption affects re-election in local units with small winning coalitions, and how corruption affects re-election in local units with large winning coalitions. The prediction from the theory is that there should be a positive and concave effect of corruption on re-election only in small winning coalition environments. Both a probit and a linear probability model (LPM) are used in estimating equation (13).

Finally, the third step is to test how the W/S ratio affects local tax surcharge rates, where the average tax surcharge rate in the year of the election 2013, $t_{i}$ is taken as the main dependent variable (Tax rate), featuring the all the same right-hand side variables as in the first two equations: 


$$
t_{i}=\rho W S_{i}+\boldsymbol{X}_{i} \gamma+\mu_{i}
$$

All of the aforementioned equations are estimated using the simple ordinary least squares (OLS) estimation (except in equation 13 where a probit is used as well). However each of them could still be biased due to endogeneity issues. For example, there could be an unobserved factor like a specific local mentality that is simultaneously affecting both a small W/S environment and a higher tendency for corruption or even taxation. In order words corruption and taxes could be higher not because of a small W/S environment, but because of something intrinsic to the community that we cannot observe. If this is the case then each estimated $\hat{\rho}$ coefficient is likely to be biased.

In order to address these concerns the empirical strategy will employ several matching techniques seeking to solve potential endogeneity problems and get an unbiased estimate of the effect a small W/S environment has on corruption, taxation, and tenure in office. Matching is a conditioning-on-observables approach for the estimation of causal effects, meaning that its application depends on selection of comparable units by the researcher. This selection depends on finding a balance between a set of observable covariates in order to make the comparison between very similar treated and controlled units. Its primary goal is to establish counterfactual inference when the data are not generated by a random process or by an experiment.

The key to a successful matching strategy is to achieve a balance based on the distribution of covariates for the treated and control units. In other words, we must make the treatment group as similar as possible to the control group in order to get a good estimate of a potential effect of the treatment on the outcome (in our case the impact of the W/S environment on corruption, taxation, and tenure). Therefore the first step before even beginning the estimation of the treatment effect is to generate comparable datasets of treated and control units, based on the set of observable covariates from the sample at hand. This paper will use several matching techniques (propensity score matching, nearest neighbor matching, radius matching, and kernel matching) and compare the results between them as a robustness check. After this it will apply a much more robust method of entropy balancing (Hainmueller, 2012; Hainmueller and $\mathrm{Xu}, 2013$ ) to generate an even better balanced sample, and compare the results. After performing the balancing of the dataset, making sure that we have comparable treatment and control units, equations (11), (12) and (14) will be estimated again in order to get the unbiased average treatment effect.

In the subsequent sections we first present the initial OLS estimates for each effect. Section 5.5 then applies the matching strategies and estimates the same equations once again using a balanced dataset to get a more precise inference on the causal effect of the W/S ratio on corruption, taxes, and tenure. 
Table 2 shows the results of equation (11) on how the W/S ratio impacts political survival. Overall the results imply that a higher W/S ratio decreases total tenure in office: a switch from a small winning coalition to a large winning coalition reduces time in office between one and one and a half years. This effect is very large given that the estimates are made using the period of a single political mandate. Across three terms in office this implies that a politician operating within a small winning coalition is likely to have one full term in office more than a politician operating within a large winning coalition. This result remains robust to the inclusion of a number of political, economic, and municipal-specific characteristics.

\section{Table 2}

Impact of winning coalition size on tenure in power

\begin{tabular}{|c|c|c|c|c|}
\hline $\begin{array}{l}\text { Dependent variable: } \\
\text { Years in power }\left(T_{i}\right)\end{array}$ & (1) & (2) & (3) & (4) \\
\hline $\mathrm{W} / \mathrm{S}$ ratio & $\begin{array}{l}-4.135 \\
(1.55)^{* * *}\end{array}$ & $\begin{array}{l}-3.779 \\
(1.56) * *\end{array}$ & $\begin{array}{l}-4.898 \\
(1.61)^{* * *}\end{array}$ & $\begin{array}{l}-3.913 \\
(1.71)^{* *}\end{array}$ \\
\hline Corruption index & & $\begin{array}{l}2.581 \\
(1.2)^{* *}\end{array}$ & $\begin{array}{l}2.446 \\
(1.24)^{* *}\end{array}$ & $\begin{array}{c}2.36 \\
(1.18)^{* *}\end{array}$ \\
\hline Size of gov coalition & $\begin{array}{l}-0.613 \\
(0.15)^{* * *}\end{array}$ & $\begin{array}{l}-0.641 \\
(0.145)^{* * *}\end{array}$ & $\begin{array}{l}-0.661 \\
(0.143)^{* * *}\end{array}$ & $\begin{array}{l}-0.681 \\
(0.143)^{* * *}\end{array}$ \\
\hline Mayor majority & $\begin{array}{l}8.889 \\
(1.13)^{* * *}\end{array}$ & $\begin{array}{l}8.851 \\
(1.14)^{* * *}\end{array}$ & $\begin{array}{l}9.078 \\
(1.11)^{* * *}\end{array}$ & $\begin{array}{c}9.332 \\
(1.107)^{* * *}\end{array}$ \\
\hline EPI & $\begin{array}{l}-1.281 \\
(0.97)\end{array}$ & $\begin{array}{r}-1.454 \\
(0.98)\end{array}$ & $\begin{array}{r}-1.725 \\
(0.97)\end{array}$ & $\begin{array}{r}-1.172 \\
(1.07)\end{array}$ \\
\hline Mayor gov & $\begin{array}{r}0.259 \\
(0.41)\end{array}$ & $\begin{array}{r}0.25 \\
(0.40)\end{array}$ & $\begin{array}{r}0.343 \\
(0.40)\end{array}$ & $\begin{array}{l}0.275 \\
(0.41)\end{array}$ \\
\hline HDZ vote share & $\begin{array}{l}2.294 \\
(1.57) \\
\end{array}$ & $\begin{array}{l}2.196 \\
(1.59) \\
\end{array}$ & $\begin{array}{l}2.843 \\
(1.54)^{*}\end{array}$ & $\begin{array}{l}2.818 \\
(1.93)\end{array}$ \\
\hline SDP vote share & $\begin{array}{l}6.424 \\
(2.15)^{* * *}\end{array}$ & $\begin{array}{l}5.915 \\
(2.18)^{* * *}\end{array}$ & $\begin{array}{l}3.339 \\
(2.42) \\
\end{array}$ & $\begin{array}{l}3.738 \\
(2.61)\end{array}$ \\
\hline Unemployment & & & $\begin{array}{l}-5.77 \\
(2.28)^{* *}\end{array}$ & $\begin{array}{l}-7.29 \\
(2.55)^{* * *}\end{array}$ \\
\hline Income $\mathrm{p} / \mathrm{c}$ & & & $\begin{array}{r}-0.0007 \\
(0.0004) \\
\end{array}$ & $\begin{array}{r}-0.0007 \\
(0.0006) \\
\end{array}$ \\
\hline Grants p/c & & & $\begin{array}{r}0.0002 \\
(0.0001) \\
\end{array}$ & $\begin{array}{c}0.0003 \\
(0.0001)^{* *}\end{array}$ \\
\hline Controls & No & No & No & Yes \\
\hline $\mathrm{N}$ & 546 & 546 & 546 & 546 \\
\hline $\mathrm{R}^{2}$ & 0.1869 & 0.1951 & 0.2102 & 0.2194 \\
\hline F-test (p-value) & $27.53(0)$ & $24.29(0)$ & $21.42(0)$ & $15.70(0)$ \\
\hline
\end{tabular}

Note: OLS regressions performed throughout. Control variables include the municipality and city specific controls: Croats, Average age, Years of education, War disabled, Settlement size, and Assembly size. Standard errors are robust to heteroskedasticity. *** denotes significance at $1 \%$, ** at $5 \%$, and $*$ at $10 \%$. 
Column (1) shows the results while including only the initial set of political variables as covariates. Moving from a local unit with a W/S ratio of 0.1 (small winning coalition environment) to a local unit with a W/S ratio of 0.4 (large winning coalition environment) decreases tenure in office by 1 year and 3 months. Column (2) adds corruption to the equation, under the hypothesis that longer tenure is likely to be conditioned by higher corruption. This is indeed the case as greater levels of corruption - moving from a zero corruption local unit to a unit where corruption is moderate, at an index value of 0.25 - increase tenure by an average of 8 months. However a switch from a zero corruption to a high corruption environment (levels of corruption at 0.5 ) increases tenure by 1 year and 4 months on average. A corrupt politician therefore stays in power longer. This also aligns well with the overall hypothesis that political survival is dependent to some extent on corruption. Interestingly the inclusion of the corruption variable decreases the magnitude of the $\mathrm{W} / \mathrm{S}$ ratio effect, but it does not lose its statistical significance. Columns (3) and (4) add other economic and municipal-specific controls. In both cases the magnitude of the corruption effect is still roughly the same, while the effect of the W/S ratio varies from 1.1 to 1.5 fewer years in office for a switch from a small winning coalition local unit to a large winning coalition local unit.

The control variables all exhibit an expected effect on tenure in office. In all cases, each additional party that is a member of the governing coalition lowers tenure by about 8 months. This makes sense as more parties in the governing coalition make that coalition unstable which affects a mayor's probability of staying in power. Furthermore, a higher proportion of deputies in the local council that support the mayor (an increase of one standard deviation of 0.145 ) increases tenure between 1.2 and 1.3 years. This is also an expected effect as more deputies from the same party as the mayor, the more likely that a mayor has a stable governing coalition in the local assembly. Essentially these two variables measure the same thing with an opposite sign. Interestingly a higher vote share for SDP in a local unit (a one standard deviation increase of 0.097 ) increases tenure by roughly 6 months, however this effect loses statistical significance once economic covariates are included. From the economic covariates, unemployment exhibits an expected negative effect on tenure, where higher unemployment (a one standard deviation increase of 0.092) in a local unit decreases time in office between 6 and 8 months on average. All of these estimated effects may seem small in absolute terms, however keep in mind that each is estimated during a single political term in office, so the effects are actually quite large.

\subsection{THE W/S RATIO AND CORRUPTION}

The results from section 5.2 have confirmed a positive impact of corruption on tenure in office, and have established that both corruption and a small winning coalition environment entail a positive impact on political tenure. This section empirically tests the second prediction of the theoretical section (and the unique prediction of the model) according to which small winning coalition environments should exhibit higher levels of corruption. Table 3 shows the results. As 
expected and hypothesized in each case a higher $\mathrm{W} / \mathrm{S}$ ratio decreases total levels of corruption. Corruption is therefore more likely to occur in small winning coalition environments. The magnitude of the effect is roughly the same across all regression equations. A one standard deviation increase (decrease) of the W/S ratio decreases (increases) corruption by 1.1 to 1.4 percentage points.

\section{TABle 3}

Impact of winning coalition size on corruption

Dependent variable:

(1)

(2)

(3)

(4)

Corruption index $\left(\boldsymbol{k}_{i}\right)$

\begin{tabular}{|c|c|c|c|c|}
\hline $\mathrm{W} / \mathrm{S}$ ratio & $\begin{array}{l}-0.138 \\
(0.06)^{* *}\end{array}$ & $\begin{array}{l}-0.122 \\
(0.06)^{* *}\end{array}$ & $\begin{array}{l}-0.121 \\
(0.06)^{*}\end{array}$ & $\begin{array}{l}-0.113 \\
(0.06)^{*}\end{array}$ \\
\hline Tax rate (prirez) & & & & $\begin{array}{c}0.267 \\
(0.129)^{* *}\end{array}$ \\
\hline Size of gov coalition & $\begin{array}{c}0.01 \\
(0.005)^{*}\end{array}$ & $\begin{array}{r}0.006 \\
(0.005)\end{array}$ & $\begin{array}{r}0.006 \\
(0.005)\end{array}$ & $\begin{array}{r}0.005 \\
(0.143)\end{array}$ \\
\hline Mayor majority & $\begin{array}{r}0.014 \\
(0.039)\end{array}$ & $\begin{array}{r}0.02 \\
(0.038)\end{array}$ & $\begin{array}{r}0.031 \\
(0.039)\end{array}$ & $\begin{array}{l}0.033 \\
(0.04)\end{array}$ \\
\hline EPI & $\begin{array}{c}0.067 \\
(0.032)^{* *}\end{array}$ & $\begin{array}{c}0.083 \\
(0.031)^{* *}\end{array}$ & $\begin{array}{c}0.078 \\
(0.032)^{* *}\end{array}$ & $\begin{array}{c}0.074 \\
(0.032)^{* *}\end{array}$ \\
\hline Mayor gov & $\begin{array}{r}0.003 \\
(0.01)\end{array}$ & $\begin{array}{l}0.001 \\
(0.01)\end{array}$ & $\begin{array}{l}0.005 \\
(0.01)\end{array}$ & $\begin{array}{l}0.006 \\
(0.01)\end{array}$ \\
\hline HDZ vote share & $\begin{array}{r}0.038 \\
(0.068)\end{array}$ & $\begin{array}{r}0.008 \\
(0.069)\end{array}$ & $\begin{array}{r}0.018 \\
(0.088) \\
\end{array}$ & $\begin{array}{r}0.014 \\
(0.089)\end{array}$ \\
\hline SDP vote share & $\begin{array}{l}0.197 \\
(0.10)^{*}\end{array}$ & $\begin{array}{r}0.05 \\
(0.10)\end{array}$ & $\begin{array}{l}0.058 \\
(0.12)\end{array}$ & $\begin{array}{l}0.063 \\
(0.12)\end{array}$ \\
\hline Unemployment & & $\begin{array}{l}0.117 \\
(0.09)\end{array}$ & $\begin{array}{r}0.092 \\
(0.101)\end{array}$ & $\begin{array}{r}0.079 \\
(0.10)\end{array}$ \\
\hline Income $\mathrm{p} / \mathrm{c}$ & & $\begin{array}{c}8.38 \times 10^{-5} \\
\left(1.48 \times 10^{-5}\right)^{* * *}\end{array}$ & $\begin{array}{c}4.59 \times 10^{-5} \\
\left(2.43 \times 10^{-5}\right)^{*}\end{array}$ & $\begin{array}{l}4.06 \times 10^{-5} \\
\left(2.4 \times 10^{-5}\right)^{*}\end{array}$ \\
\hline Grants $\mathrm{p} / \mathrm{c}$ & & $\begin{array}{l}-8.14 \times 10^{-6} \\
\left(3.17 \times 10^{-6}\right)^{* *}\end{array}$ & $\begin{array}{l}-9.42 \times 10^{-6} \\
\left(4.2 \times 10^{-6}\right)^{* *}\end{array}$ & $\begin{array}{l}-9.44 \times 10^{-6} \\
\left(4.1 \times 10^{-6}\right)^{* *}\end{array}$ \\
\hline Controls & No & No & Yes & Yes \\
\hline $\mathrm{N}$ & 546 & 546 & 546 & 546 \\
\hline $\mathrm{R}^{2}$ & 0.0498 & 0.0989 & 0.1088 & 0.1158 \\
\hline F-test (p-value) & $4.56(0)$ & $8.54(0)$ & $6.90(0)$ & $6.99(0)$ \\
\hline
\end{tabular}

Note: OLS regressions performed throughout. Control variables include the municipality and city specific controls: Croats, Average age, Years of education, War disabled, Settlement size, and Assembly size. Standard errors are robust to heteroskedasticity. *** denotes significance at $1 \%$, ** at $5 \%$, and $*$ at $10 \%$.

Graph 1 below plots the impact of the W/S ratio on corruption. Predicted levels of corruption (predicted from the estimates of column 3) are plotted on the y-axis, and the $\mathrm{W} / \mathrm{S}$ ratio is plotted on the $\mathrm{x}$-axis. As anticipated by the underlying theory the effect is clearly negative and confirms the results from table 3. 
GRAPH 1

Smaller winning coalition size environments on average exhibit greater levels of corruption

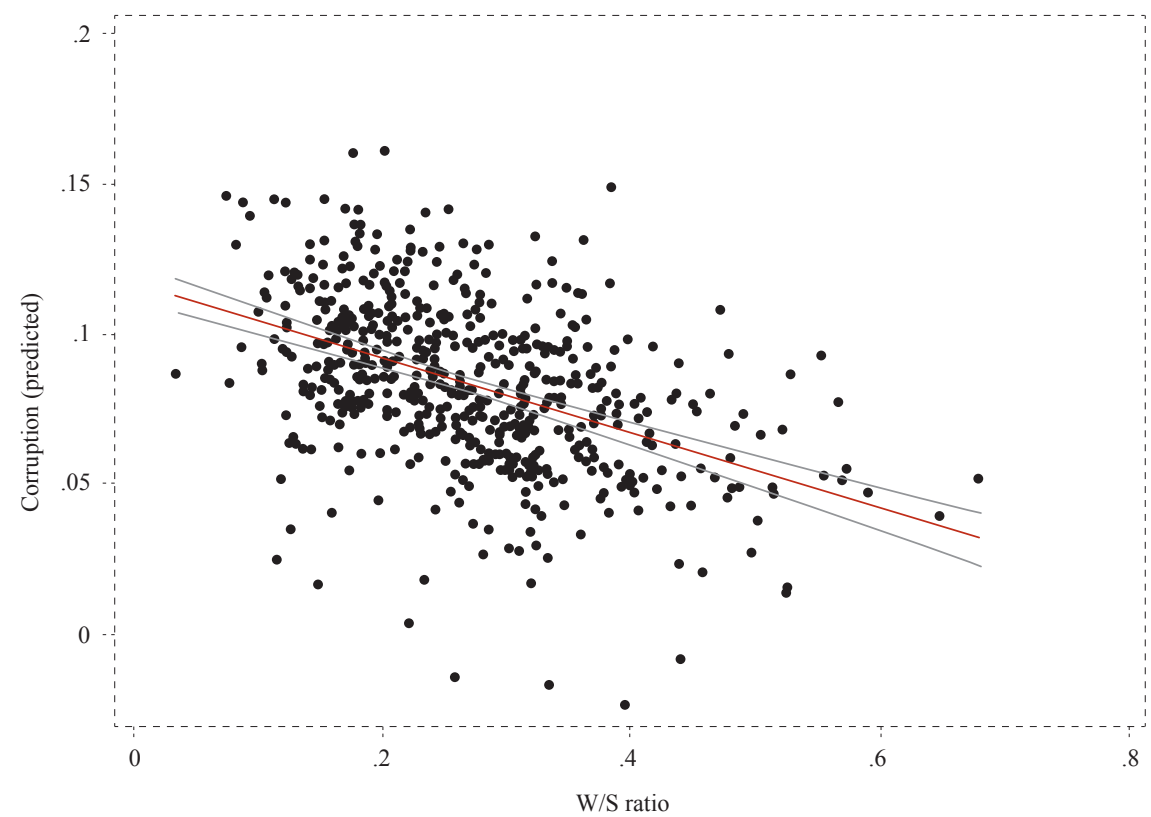

Note: Corruption is predicted from equation (12).

Source: Author's own calculations.

The theoretical prediction from the model in equation (10) was also that corruption should be higher in areas with greater political polarization $(\psi \underline{\lim } 0)$, i.e. in areas of higher ideological uniformity, and in areas with higher income and higher local taxes. This too has been shown in table 3. Greater political polarization, i.e. greater ideological uniformity of a city or municipality, results in higher corruption. This makes sense given that ideologically uniform local environments are likely to accept higher corruption from their local mayor if he or she comes from the "correct" political spectrum. Also, greater income per capita in a local unit implies higher corruption, whereas more grants received by a local unit (i.e. the poorer the city or municipality) imply lower corruption.

The final column includes the local tax surcharge rate as an additional covariate. As predicted by the model in equation (10) cities or municipalities whose mayors set up higher tax rates tend to have greater levels of corruption. The effect is robust even after controlling for total tax revenues (not shown, available upon request). The reason for this could be simple: higher taxes imply higher revenues and hence more opportunities to engage in corruption. This is not necessarily a causal effect, but it testifies of an interesting relationship that will be examined in further sections. 


\subsubsection{Corruption and re-election in large and small winning coalitions}

The previous two sections confirmed a relationship between small winning coalitions and political longevity as well as potential corruption. This could mean that the relationship between corruption and re-election is bounded and encouraged only within a small winning coalition environment. In order to test whether this is true, this section looks at the relationship between corruption and re-election in two different sets of winning coalition environments. It estimates equation (13) and follows the assumption of a quadratic relationship between corruption and re-election according to Vuković (2017).

The expectation is that there will be a positive (yet non-linear) relationship between corruption and re-election only in small winning coalition local units (those with lower levels of transparency and political accountability), and that there will be no such relationship in local units with a larger winning coalition (which have higher levels of transparency and political accountability).

\section{TABLE 4}

Impact of corruption on re-election in small and large winning coalitions

\begin{tabular}{|c|c|c|c|c|}
\hline \multirow[t]{2}{*}{$\begin{array}{l}\text { Dependent variable: } \\
\text { Re-election }\left(R_{i}\right)\end{array}$} & \multicolumn{2}{|c|}{$\begin{array}{c}\text { Small winning coalition } \\
(\mathrm{W} / \mathrm{S}<\mathbf{0 . 2 6})\end{array}$} & \multicolumn{2}{|c|}{$\begin{array}{c}\text { Large winning coalition } \\
(\mathrm{W} / \mathrm{S}>\mathbf{0 . 2 6})\end{array}$} \\
\hline & (1) Probit & (2) LPM & (3) Probit & (4) LPM \\
\hline Corruption $k_{i}$ & $\begin{array}{c}0.948 \\
(0.508)^{*}\end{array}$ & $\begin{array}{c}0.954 \\
(0.524)^{*}\end{array}$ & $\begin{array}{r}0.229 \\
(0.353)\end{array}$ & $\begin{array}{r}0.318 \\
(0.447)\end{array}$ \\
\hline $\begin{array}{l}\text { Corruption } \\
\text { squared } k_{i}^{2}\end{array}$ & $\begin{array}{l}-1.868 \\
(0.948)^{* *}\end{array}$ & $\begin{array}{l}-1.891 \\
(0.927)^{* *}\end{array}$ & $\begin{array}{l}-1.182 \\
(0.795)\end{array}$ & $\begin{array}{r}-1.576 \\
(1.401)\end{array}$ \\
\hline Controls & Yes & Yes & Yes & Yes \\
\hline $\mathrm{N}$ & 295 & 295 & 250 & 250 \\
\hline Pseudo $\mathrm{R}^{2}$ & 0.1276 & 0.1522 & 0.2717 & 0.1821 \\
\hline Wald/F-test (p-value) & $43.67(0)$ & $4.36(0)$ & $40.93(0)$ & $1.26(0.19)$ \\
\hline
\end{tabular}

Note: Columns 1 and 3 report the results from the probit estimations (and they have the Wald test and a Pseudo $R^{2}$ reported), while columns 2 and 4 report the results from the OLS estimations (which have the F-test and the regular $R^{2}$ reported). The full list of control variables is the same as in column 4 of tables 2 and 3 . Standard errors are robust to heteroskedasticity. *** denotes significance at $1 \%$, ** at $5 \%$, and $*$ at $10 \%$.

Table 4 presents the results and confirms the intuition where the effect of corruption on reelection is both higher and statistically significant in municipalities with a smaller W/S ratio (smaller winning coalition). This effect should be calculated as $k_{i}^{*}=\left|\frac{\hat{\beta}_{1}}{2 \hat{\beta}_{2}}\right|$, where $k_{i}^{*}$ is the marginal cutoff value of corruption while $\hat{\beta}_{1}$ and $\hat{\beta}_{2}$ are estimated regression coefficients from equation (13). The cut-off value for corruption in small winning coalition environments is $25.2 \%$. This means that politicians maximize their chances of re-election when the share of suspicious procurements in total procurements ${ }^{4}$ is about one fourth. This is a relatively high level of

\footnotetext{
${ }^{4}$ This is the official definition of the Total index corruption proxy, according to Vuković (2017).
} 
corruption persistence given that voters usually lack the necessary information to punish such behavior. In municipalities with a high W/S ratio (larger winning coalition) the effect is much smaller - the cut-off value of corruption is $10.1 \%$ however it is statistically indistinguishable from zero. This suggests that corruption does not aid in re-election chances in large winning coalition environments, but only in small ones. In other words, in places where it is easier for politicians to form long-term connections with quasi-entrepreneurs, it is more likely that by engaging in such activities they will increase their chances of re-election. No such effect exists in areas where it is more difficult to successfully satisfy a group of key supporters.

\subsection{TAXES, CORRUPTION AND THE W/S RATIO}

The final theoretical prediction is that small winning coalition environments should have higher tax rates. This section will present the results from equation (14) and will in addition test the reverse impact of corruption on tax rates. The main dependent variable represents the tax surcharge rate applied on top of the main income tax rate; however it will be referred to simply as local tax rate, given that this rate is under full jurisdiction of the local mayor and his or her administration. There is an upper boundary for how high each city or municipality can set this rate, which is based on population size, but any decision on tax rates within this boundary is carried out by the local mayor. It therefore makes sense to use this variable as yet another measure of a local mayor's power structure.

\section{GraPH 2}

A small winning coalition environment has on average higher local tax rates

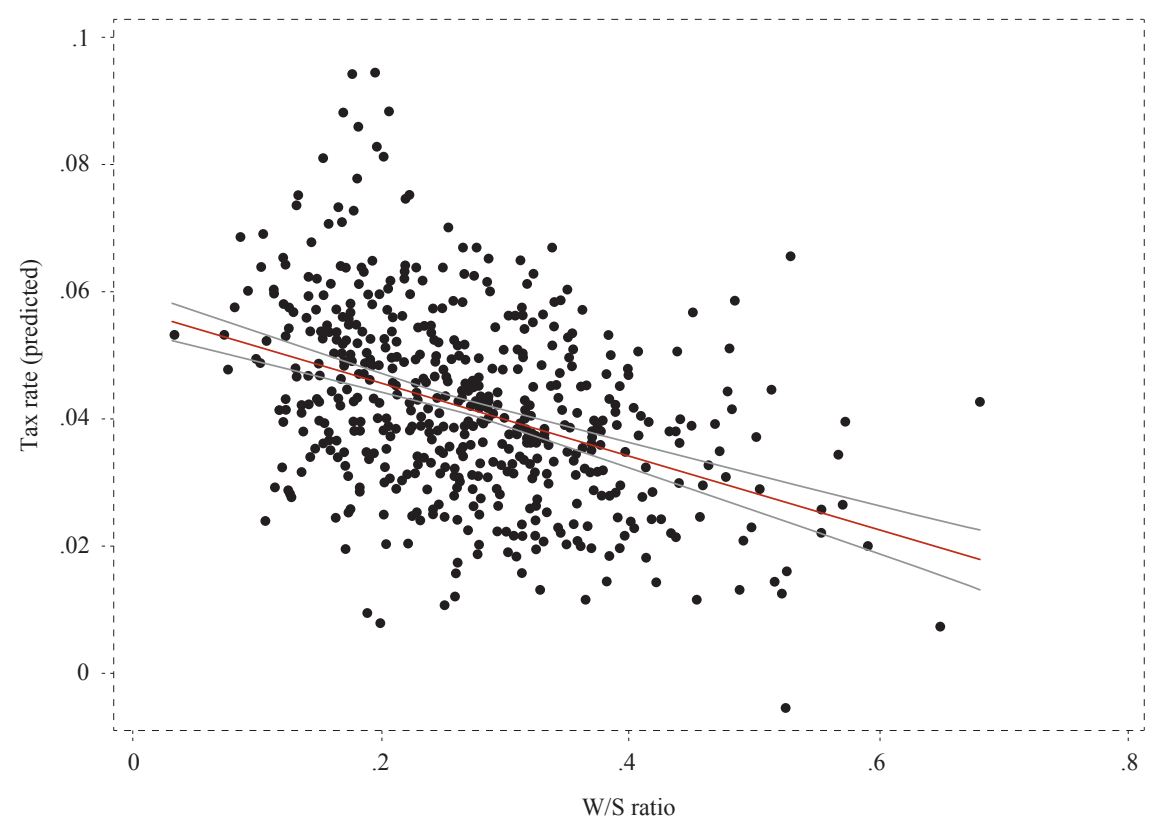

Note: Tax rates are predicted from equation (14).

Source: Author's own calculations. 
Table 5 shows the results. Both the W/S ratio and the corruption index entail an effect on local taxes of roughly similar magnitude, but in different directions. For example, moving from a small winning coalition environment $(\mathrm{W} / \mathrm{S}=0.1)$ to a large winning coalition environment $(\mathrm{W} / \mathrm{S}=0.4)$ the local tax rate is estimated to be between 1.2 and 1.5 percentage points lower. This is a very large effect given that the mean local tax rate is $4.15 \%$. In other words a small winning coalition environment is likely to be characterized by much higher tax rates (around 30\% higher taxes), even when controlling for population size and all other important factors. Graph 2 shows this relationship graphically estimating the level of tax rates using the regression equation from column (4). Similarly, a move from a zero corruption to a high corruption environment (from 0 to 0.5 value of the corruption index) will increase local tax rates by between 1.5 and 2.6 percentage points. This effect, just like the previous one, is very large and statistically significant.

\section{TABLE 5}

Impact of winning coalition size on local tax rates

\begin{tabular}{|c|c|c|c|c|}
\hline $\begin{array}{l}\text { Dependent variable: } \\
\text { Tax rate }\left(t_{i}\right)\end{array}$ & (1) & (2) & (3) & (4) \\
\hline $\mathrm{W} / \mathrm{S}$ ratio & $\begin{array}{l}-0.051 \\
(0.016)^{* * *}\end{array}$ & $\begin{array}{l}-0.039 \\
(0.016)^{* *}\end{array}$ & $\begin{array}{l}-0.041 \\
(0.018)^{* *}\end{array}$ & $\begin{array}{r}-0.023 \\
(0.019)\end{array}$ \\
\hline Corruption index & $\begin{array}{c}0.053 \\
(0.016)^{* * *}\end{array}$ & $\begin{array}{c}0.034 \\
(0.015)^{* *}\end{array}$ & $\begin{array}{c}0.030 \\
(0.015)^{* *}\end{array}$ & $\begin{array}{c}0.029 \\
(0.014)^{* *}\end{array}$ \\
\hline Size of gov coalition & & & $\begin{array}{c}0.005 \\
(0.002)^{* * *}\end{array}$ & $\begin{array}{c}0.004 \\
(0.002)^{* *}\end{array}$ \\
\hline Mayor majority & & & $\begin{array}{r}-0.012 \\
(0.015)\end{array}$ & $\begin{array}{r}-0.007 \\
(0.016)\end{array}$ \\
\hline EPI & & & $\begin{array}{r}0.003 \\
(0.012)\end{array}$ & $\begin{array}{r}0.011 \\
(0.012)\end{array}$ \\
\hline Mayor gov & & & $\begin{array}{r}-0.004 \\
(0.005)\end{array}$ & $\begin{array}{r}-0.005 \\
(0.005)\end{array}$ \\
\hline HDZ vote share & & & $\begin{array}{r}0.022 \\
(0.023)\end{array}$ & $\begin{array}{r}0.013 \\
(0.025)\end{array}$ \\
\hline SDP vote share & & & $\begin{array}{r}-0.017 \\
(0.03)\end{array}$ & $\begin{array}{r}-0.021 \\
(0.03)\end{array}$ \\
\hline Unemployment & & $\begin{array}{c}0.084 \\
(0.024)^{* * *} \\
\end{array}$ & $\begin{array}{c}0.063 \\
(0.027)^{* *}\end{array}$ & $\begin{array}{r}0.046 \\
(0.031) \\
\end{array}$ \\
\hline Income $\mathrm{p} / \mathrm{c}$ & & $\begin{array}{c}3.05 \times 10^{-5} \\
\left(5.87 \times 10^{-6}\right)^{* * *}\end{array}$ & $\begin{array}{c}3.11 \times 10^{-5} \\
\left(6.13 \times 10^{-6}\right)^{* * *}\end{array}$ & $\begin{array}{l}1.88 \times 10^{-5} \\
\left(8.2 \times 10^{-6}\right)^{* *}\end{array}$ \\
\hline Grants $\mathrm{p} / \mathrm{c}$ & & $\begin{array}{l}-2.37 \times 10^{-6} \\
\left(1.7 \times 10^{-6}\right)\end{array}$ & $\begin{array}{l}-2.59 \times 10^{-6} \\
\left(1.7 \times 10^{-6}\right)\end{array}$ & $\begin{array}{l}3.72 \times 10^{-7} \\
\left(1.8 \times 10^{-6}\right)\end{array}$ \\
\hline Controls & No & No & No & Yes \\
\hline $\mathrm{N}$ & 546 & 546 & 546 & 546 \\
\hline $\mathrm{R}^{2}$ & 0.0442 & 0.0958 & 0.1208 & 0.1513 \\
\hline F-test (p-value) & $11.62(0)$ & $10.37(0)$ & $6.19(0)$ & $5.75(0)$ \\
\hline
\end{tabular}

Note: OLS regressions performed throughout. Control variables include the municipality and city specific controls: Croats, Average age, Years of education, War disabled, Settlement size, and Assembly size. Standard errors are robust to heteroskedasticity. *** denotes significance at $1 \%$, ** at $5 \%$, and $*$ at $10 \%$. 
Together these two effects confirm the intuition set out in the theoretical section, according to which tax rates are likely to be higher in small winning coalition environments where corruption is larger. In other words, cities and municipalities which are unlucky to be existing within a small winning coalition environment, where politicians can easily exploit the logic of political power to keep themselves in office for long periods of time, will have a mayor who is more likely to be corrupt and keep tax rates high.

\subsection{MATCHING}

In order to get a better estimation of the potential causal effect of winning coalition environments on corruption, taxes, and tenure, a matching procedure is done in order to balance the treated and control units based on a set of used covariates. In our case the non-random treatment is the previously defined binary indicator of a small and large winning coalition environment, $W / S$ binary, where a small winning coalition is given the value of 0 , and a large winning coalition is given a value of 1 . The covariates, with their summary statistics given in table 1 , are the same control variables used throughout tables 2,3 and 4 . The balancing of the dataset is done with respect to these covariates in order to make the small and large winning coalition environments as similar as possible to draw a causal inference.

In order to balance the dataset several matching techniques will be applied. This is done primarily as a robustness check so that our results do not depend on method specification. The first matching method is the default propensity score (PS) matching. In order to evaluate how good it balanced the dataset we need to perform visualizations of balance checks. Graph 3 reports how well each of the four used algorithms matched the covariates by showing the standardized biases (PS matching is shown in the first upper left panel). It reports the graphical results of a t-test on whether the mean value of each covariate is the same in the treatment and control groups. The closer the matched values (denoted by $\mathrm{X}$ in each of the graphs) are to the horizontal line, the lower the standardized bias across covariates, and the better matched the sample gets. By observing the pre-matched means of the covariates (denoted by black dots in all charts of graph 3 ) it is easy to see that there were clear differences in the distributions of covariates before performing the matching. For example, small winning coalition environments were already more likely to have smaller governing coalitions, greater mayor majorities, and lower levels of political polarization which could have affected both total corruption and tenure in office. Running a regression without taking this into account could have overestimated the effect of the W/S ratio on both corruption and tenure. This is why it is important to perform a balancing of treatment and control groups with respect to the given covariates. 

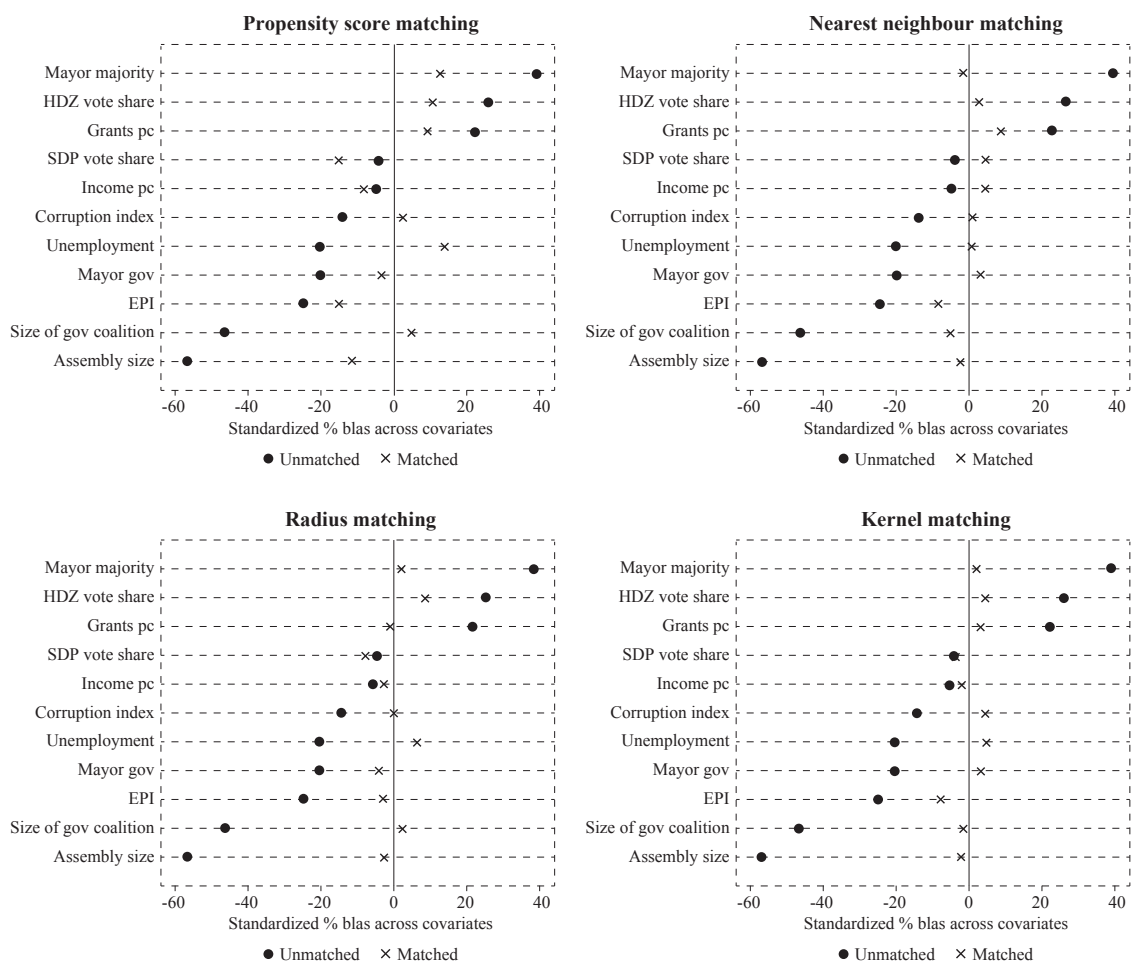

Note: Each $x$-axis shows the standardized bias across covariates (the lower the bias, i.e. the closer the matched values to 0 , the better the balancing), while each y-axis shows the list of covariates used in the matching procedure.

Source: Author's own calculations.

After matching, it is obvious that a better balance is achieved across all covariates (shown by $\mathrm{X}$ in each graph). The percentage differences in means in treated and control units across each covariate for all the algorithms are very low and statistically insignificant (the lowest p-value across all balance tests is 0.23 ), meaning that we can safely conclude that each matching algorithm produced a well-balanced dataset.

There are obvious differences however. Different matching techniques are usually applied until one of them delivers the optimally balanced dataset. Even though the default propensity score procedure did produce a reasonably well-balanced dataset (shown in the upper left panel of graph 3), other algorithms, in particular kernel, were matching even better. It should be mentioned that several different variations of each algorithm were tested until reaching the one with the lowest bias. Several values of the nearest neighbour algorithm were used (2, 3, 5, 10, and 12 nearest controls per one treatment). The nearest neighbour matching matches the best controls for each unit in the treatment group based on the relative distance of the 
control to the treatment unit (hence neighbour). The upper right panel in graph 3 shows the matched dataset using 10 controls per one treatment, and it is the one that had the lowest standardized bias. For radius matching, which establishes a maximum propensity score radius, and matches units based on an established calliper, the following calliper values were used: $0.2,0.1,0.08,0.05,0.02$., and 0.01 . The final one, with a calliper of 0.01 was the best matched and is shown in the lower left panel of graph 3. Finally, the lower right panel shows kernel matching, where a normal and a tricube kernel types were used. Kernel matching uses a kernel-weighted average of the outcome for all control units, where the weight indicates a proportion of distance between control and treatment units. The tricube kernel type was the one that offered the lowest bias. The kernel algorithm balanced the sample better than the other three chosen algorithms (it had the lowest overall standardized bias), with nearest neighbour matching coming in second.

\subsubsection{Estimating the effect after matching}

After having successfully achieved a balance between treatments and controls across all the covariates, the next step is to engage in estimation. Table 6 shows the estimates for a linear OLS regression of the treatment effect of a small winning coalition environment on tenure, corruption, and local taxes, across each of the balanced datasets for different matching algorithms (each column represents results for a different matching algorithm). The coefficients do not differ substantially from each other. They all suggest a highly significant and negative effect of the $\mathrm{W} / \mathrm{S}$ ratio on tenure, corruption, and taxes, as we have shown in sections 5.2 to 5.4. In terms of effect size, a city or municipality with a small winning coalition increases tenure by an average of 6 to 12 months, increases corruption by an average 4.6 to 5.2 percentage points, and increases tax rates by an average of 0.8 to 1 percentage points when compared to a similar city or municipality with a large winning coalition. These average treatment effects are not too different from the estimated coefficients reported in tables 2, 3 and 5, except in the case of the impact on corruption, where the effect is now several times larger. The reason for this is a different unit of comparison - in section 5.3 the estimated effect was looking at a one standard deviation increase in the W/S ratio (a change of the ratio by 0.1 ), whereas now we are interpreting an indicator variable change (the equivalent of which would be an increase of the W/S ratio by 0.3 , which would according to table 3 yield an effect on corruption of 3.6 percentage points, which is still lower but it is relatively close). 


\begin{tabular}{|c|c|c|c|c|}
\hline & PS matching & NN matching & $\begin{array}{c}\text { Radius } \\
\text { matching }\end{array}$ & $\begin{array}{c}\text { Kernel } \\
\text { matching }\end{array}$ \\
\hline $\begin{array}{l}\text { Impact of } W / S \\
\text { on tenure }\left(T_{i}\right)\end{array}$ & $\begin{array}{l}-0.987 \\
(0.440)^{* *}\end{array}$ & $\begin{array}{l}-0.543 \\
(0.32)^{*}\end{array}$ & $\begin{array}{l}-0.644 \\
(0.338)^{*}\end{array}$ & $\begin{array}{l}-0.669 \\
(0.302)^{* *}\end{array}$ \\
\hline $\mathrm{R}^{2}$ & 0.3059 & 0.2221 & 0.2144 & 0.2430 \\
\hline F-test (p-value) & $12.9(0)$ & $13.09(0)$ & $10.29(0)$ & $13.89(0)$ \\
\hline $\begin{array}{l}\text { Impact of W/S } \\
\text { on corruption }\left(k_{i}\right)\end{array}$ & $\begin{array}{r}-0.0558 \\
(0.038)\end{array}$ & $\begin{array}{l}-0.0526 \\
(0.026)^{* *}\end{array}$ & $\begin{array}{r}-0.0367 \\
(0.028)\end{array}$ & $\begin{array}{l}-0.046 \\
(0.026)^{*}\end{array}$ \\
\hline $\mathrm{R}^{2}$ & 0.0846 & 0.088 & 0.0713 & 0.0912 \\
\hline F-test (p-value) & $1.85(0.04)$ & $2.56(0)$ & $2.59(0)$ & $2.67(0)$ \\
\hline $\begin{array}{l}\text { Impact of } \mathrm{W} / \mathrm{S} \\
\text { on tax rates }\left(t_{i}\right)\end{array}$ & $\begin{array}{l}-0.0102 \\
(0.005)^{*}\end{array}$ & $\begin{array}{l}-0.0086 \\
(0.004)^{* *}\end{array}$ & $\begin{array}{l}-0.0097 \\
(0.003)^{* *}\end{array}$ & $\begin{array}{l}-0.0099 \\
(0.003)^{* * *}\end{array}$ \\
\hline $\mathrm{R}^{2}$ & 0.1855 & 0.1290 & 0.0962 & 0.1168 \\
\hline F-test (p-value) & $4.85(0)$ & $3.81(0)$ & $4.25(0)$ & $4.29(0)$ \\
\hline Controls & Yes & Yes & Yes & Yes \\
\hline $\mathrm{N}$ & 257 & 484 & 546 & 537 \\
\hline
\end{tabular}

Note: The four matching algorithms are: (1) propensity score matching, (2) nearest neighbor matching, (3) radius matching, and (4) kernel matching. After each matching procedure an OLS regression was performed to estimate the impact of the W/S ratio on tenure, corruption and tax rates. The full list of control variables is the same as in column 4 of tables 2 and 3. Standard errors are robust to heteroskedasticity. $* * *$ denotes significance at $1 \%, * *$ at $5 \%$, and $*$ at $10 \%$.

\subsubsection{Entropy balancing and comparison of average treatment effects}

The different matching algorithms all performed a decent balancing of the dataset and have all suggested a positive effect of small winning coalition environments on tenure, taxes, and corruption. In addition to the used algorithms there is another matching method that has proven to be even better and superior to all of the previously used ones. Entropy balancing (Hainmueller, 2012) is a multivariate reweighting method that depends on specifying the moment conditions of covariates in the treatment and control groups in order to match them. Its algorithm prevents the loss of information by predefining the balance conditions and as such "always [...] improves on the covariate balance achieved by conventional preprocessing methods" (Hainmueller and Xu, 2013). This method also enables balancing across joint distributions of covariates, which is achieved by including interaction terms. Its main advantage over all other methods is its accuracy in balancing the sample, and consequentially its accuracy in establishing the treatment effect.

When applying entropy balancing, the results are clear: it provides a much better match across the covariates than all four matching methods used in the previous section. Graph 4 compares on a single graph the differences in means for all the covariates (again looking at the standardized bias, as in graph 3). It compares the entropy balanced sample with the unmatched sample and the default propensity score matching procedure (replicated for the same interaction variables used in entropy balancing). A simple visual inspection suggests that the dataset was 
extremely well-balanced using the entropy balancing approach. All of the mean values of for the treatment and the control covariates are almost exactly the same. This clearly suggests a superior matching method and it implies that we are now able to perform a quasi-experimental estimation of the average treatment effect on exactly the same treatment and control units that differ in one single factor: having a small or large winning coalition environment.

\section{Graph 4}

A balanced sample using entropy balancing (triangles), compared with an unbalanced sample (diamonds), and a sample matched using propensity score matching (circles)

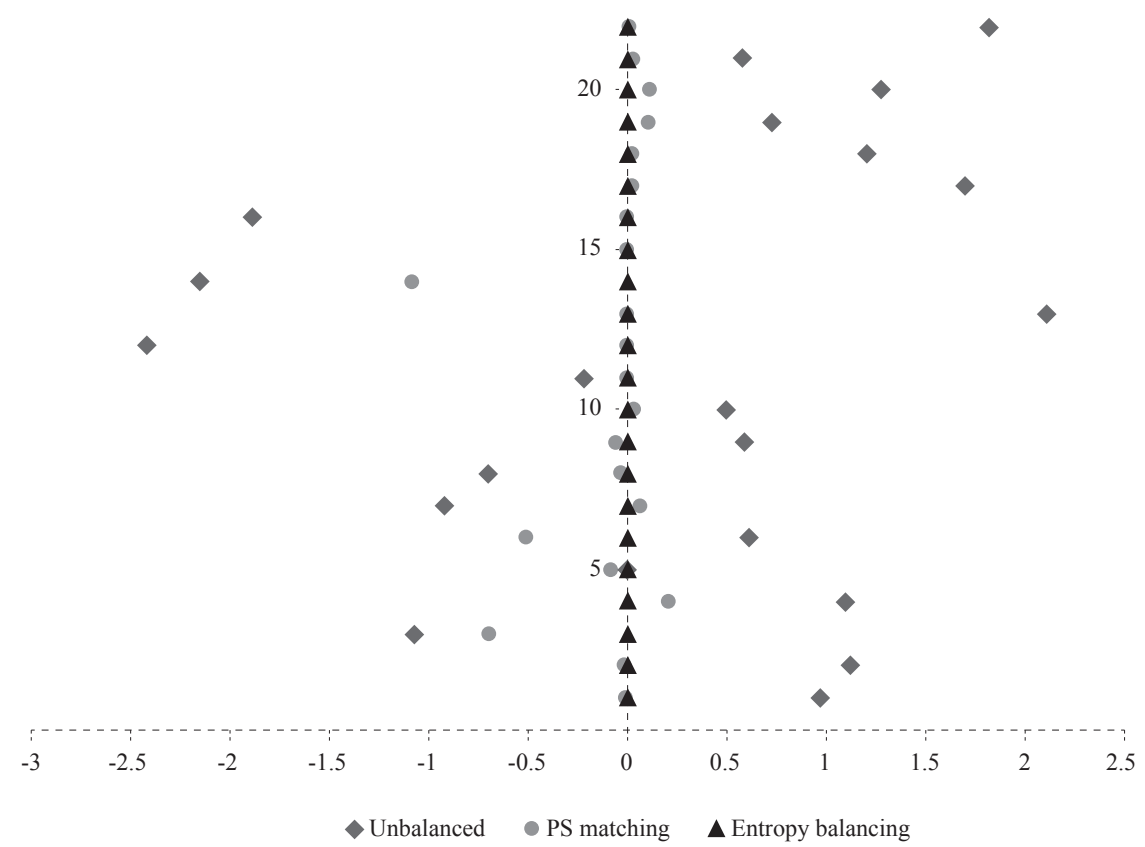

Note: Entropy balancing performs an almost perfectly balanced sample against a set of 22 covariates in total on the $y$-axis (these include all the covariates used in the initial estimations plus a few interaction terms created by the ebalancing algorithm). The $x$-axis measures the standardized bias, the same as in graph 3.

Source: Author's own calculations.

We now use the entropy balanced dataset to again generate the treatment effect of a small winning coalition on tenure, corruption, and taxes. The results are reported in table 7 comparing the estimates after entropy balancing, propensity score matching, and an OLS for the unmatched sample (these results differ from the initial ones estimated in tables 2, 3 and 5 given that the main independent variable is a binary indicator rather than a continuous variable). The coefficients for entropy balancing are slightly higher than the propensity score matching estimates, and carry greater statistical power. When compared to an unmatched dataset, the entropy balancing estimated coefficients are again larger and in the same expected direction. According to the entropy balancing estimates, a city or municipality 
with a small winning coalition increases tenure by an average of 10 months, increases corruption by an average of 6 percentage points, and increases local tax rates by 1.2 percentage points when compared to a similar city or municipality with a large winning coalition. Each of these effects are not too different from the unmatched sample estimates, however they do present us with more robust evidence of the actual treatment effect in each of the hypothesized scenarios.

TABLE 7

Entropy balancing

(1)

\begin{tabular}{|c|c|c|c|}
\hline & $\begin{array}{l}\text { Entropy } \\
\text { balancing }\end{array}$ & $\begin{array}{l}\text { Propensity score } \\
\text { matching }\end{array}$ & $\begin{array}{c}\text { Unmatched } \\
\text { sample }\end{array}$ \\
\hline $\begin{array}{l}\text { Impact of } W / S \\
\text { on tenure }\left(T_{j}\right)\end{array}$ & $\begin{array}{l}-0.857 \\
(0.275)^{* * *}\end{array}$ & $\begin{array}{l}-0.987 \\
(0.440)^{* *}\end{array}$ & $\begin{array}{l}-0.62 \\
(0.30)^{* *}\end{array}$ \\
\hline $\mathrm{R}^{2}$ & 0.2519 & 0.3059 & 0.2018 \\
\hline F-test (p-value) & $23.88(0)$ & $12.9(0)$ & $20.49(0)$ \\
\hline $\begin{array}{l}\text { Impact of W/S } \\
\text { on corruption }\left(k_{i}\right)\end{array}$ & $\begin{array}{l}-0.0602 \\
(0.030)^{* *}\end{array}$ & $\begin{array}{r}-0.0558 \\
(0.038)\end{array}$ & $\begin{array}{l}-0.054 \\
(0.026)^{* *}\end{array}$ \\
\hline $\mathrm{R}^{2}$ & 0.0856 & 0.0846 & 0.0752 \\
\hline F-test (p-value) & $3.09(0)$ & $1.85(0.04)$ & $5.21(0)$ \\
\hline $\begin{array}{l}\text { Impact of } W / S \\
\text { on tax rates }\left(t_{j}\right)\end{array}$ & $\begin{array}{l}-0.012 \\
(0.004)^{* * *}\end{array}$ & $\begin{array}{l}-0.0102 \\
(0.005)^{*}\end{array}$ & $\begin{array}{l}-0.0097 \\
(0.037)^{* *}\end{array}$ \\
\hline $\mathrm{R}^{2}$ & 0.184 & 0.1855 & 0.1245 \\
\hline F-test (p-value) & $3.51(0)$ & $4.85(0)$ & $6.45(0)$ \\
\hline Controls & Yes & Yes & Yes \\
\hline $\mathrm{N}$ & 546 & 257 & 546 \\
\hline
\end{tabular}

Note: The first column reports the estimates of the three given relationships after entropy balancing, the second replicates the same results for propensity score matching from column 1 in table 6, and the final are OLS estimates from an unmatched sample reported in column 4 of tables 2, 3 and 5. The full list of control variables is the same as in column 4 of tables 2 and 3. Standard errors are robust to heteroskedasticity. $* * *$ denotes significance at $1 \%, * *$ at $5 \%$, and $*$ at $10 \%$.

Based on the entire set of results from all matching procedures applied, the conclusion is that there is a positive causal effect of a small winning coalition environment on tenure, corruption and taxes (adhering to the assumptions of the selection on observables approach). This means that in Croatia the systemic corruption is indeed supported by an environment in which institutional and legal frameworks are personalized and hence discourage development. A city or municipality that has these characteristics is more likely to be subject to usurpation of budgetary resources for private gains and higher taxes by a politician that is likely to stay in power for a long period of time.

\section{CONCLUSION}

This paper has made an important contribution to the existing literature on corruption and institutional deficits in Croatia. It has defined a specific environment in which corruption, lack of transparency, lack of accountability, and high taxes coexist. It is the same environment in which, most likely because of low account- 
ability and low transparency, local mayors can stay in power for long periods of time. Such mayors, because their tenure in office depends on satisfying only a selected group of loyal voters, are free to engage in corrupt activities as well as set high tax rates. The paper's two main contributions have been a successful theoretical extension of the selectorate theory to include a direct link between small winning coalition environments and corruption, and a successful empirical verification of the selectorate theory in Croatia that confirms the adverse effect of small winning coalitions on corruption, taxes, and tenure. We now have a systematic explanation of why Croatian voters do not punish corrupt politicians.

This explanation is arguably only one part of a much wider issue that includes mentality, culture, historical heritage, and a range of other factors. In addition, there are several potential drawbacks of the research. The dataset is limited to only a cross-section of corruption during a single political mandate. It would have been more intuitive to observe a time series of corruption, particularly to look at how things have changed before and after the 2009 elections when the new law granting more power to mayors had been enacted. Finally, the very definition of corruption could easily underestimate total corruption in a municipality given that it does not include an arguably even bigger source of local corruption - changes in urban planning laws. Future research should attempt to address these drawbacks in order to make an even better indicator of corruption, and test it across several political terms.

Even with these limitations the main contributions of the paper redefine Croatia within a new theoretical framework for analysis. The findings confirm that Croatia is a worrying phenomenon; however the logic of political survival of Croatian politicians is no different than in any other country. The difference is only in institutions that either prevent or encourage corrupt behavior. Countries with clear and enforceable rules manage to prevent power-hungry individuals from usurping social and market outcomes, while countries that lack such rules or lack enforceability of existing rules are sentenced to vicious cycles of bad equilibria. A change of such a social order must come from an institutional push, encouraging both greater transparency and accountability to the voters, and credibly punishing politicians when they break the rules.

\section{Disclosure statement}

I state that I have no conflict of interest that might influence the results or interpretation of my manuscript. 


\section{TABLe A1}

Variables used in analysis, their description and sources

\begin{tabular}{ll} 
Variable & Description \\
\hline W/S ratio & $\begin{array}{l}\text { Winning coalition divided } \\
\text { by the entire selectorate } \\
\text { (votes for incumbent divided } \\
\text { by all eligible voters) }\end{array}$ \\
& \\
& $\begin{array}{l}\text { Weighted average of all the given } \\
\text { proxies of corruption defined } \\
\text { through various cases of potentially } \\
\text { forruption } \\
\text { index }\end{array}$ \\
&
\end{tabular}

Source

State Electoral Commission of the RC: http://www.izbori.hr/ izbori/dip_ws.nsf/public/ index?open\&id=BF0A\& Vukovic (2017), based on interviews with key stakeholders in the procurement process. Source of procurements: Official Gazette of the Republic of Croatia: https://eojn.nn.hr/ Oglasnik/

\section{Ministry of Finance,}

Tax Administration:

Tax rate (prirez) $\begin{aligned} & \text { Local tax surcharge rate } \\ & \text { on income tax }\end{aligned}$ https://www.porezna-uprava.hr/ HR_porezni_sustav/Stranice/ Popisi/Stope.aspx

\begin{tabular}{|c|c|c|}
\hline Re-election & $\begin{array}{l}=1 \text { when incumbent mayor gets } \\
\text { re-elected, }=0 \text { otherwise }\end{array}$ & $\begin{array}{l}\text { State Electoral Commission } \\
\text { of the RC }\end{array}$ \\
\hline Years in power & Total years in power until 2013 & $\begin{array}{l}\text { State Electoral Commission } \\
\text { of the RC }\end{array}$ \\
\hline Turnout & $\begin{array}{l}\text { Municipality-level turnout in the } \\
2013 \text { local election }\end{array}$ & $\begin{array}{l}\text { State Electoral Commission } \\
\text { of the RC }\end{array}$ \\
\hline HDZ vote share & $\begin{array}{l}\text { Proportion of municipal vote for the } \\
\text { HDZ in the } 2011 \text { national election }\end{array}$ & $\begin{array}{l}\text { State Electoral Commission } \\
\text { of the RC }\end{array}$ \\
\hline SDP vote share & $\begin{array}{l}\text { Proportion of municipal vote for the } \\
\text { SDP in the } 2011 \text { national election }\end{array}$ & $\begin{array}{l}\text { State Electoral Commission } \\
\text { of the RC }\end{array}$ \\
\hline $\begin{array}{l}\text { Mayor for } \\
\text { government }\end{array}$ & $\begin{array}{l}=1 \text { when mayor from the same party } \\
\text { as the national government; } \\
=0 \text { otherwise }\end{array}$ & $\begin{array}{l}\text { Glaurdić and Vuković (2017); } \\
\text { source of original data: State } \\
\text { Electoral Commission of the RC }\end{array}$ \\
\hline EPI & $\begin{array}{l}\text { Electoral polarization index, based } \\
\text { on municipality-level results in the } \\
\text { directly preceding national election }\end{array}$ & $\begin{array}{l}\text { Glaurdić and Vuković (2017); } \\
\text { source of original data: State } \\
\text { Electoral Commission of the RC }\end{array}$ \\
\hline $\begin{array}{l}\text { Size of } \\
\text { governing } \\
\text { coalition }\end{array}$ & $\begin{array}{l}\text { Number of seats the governing } \\
\text { coalition has in the local assembly }\end{array}$ & $\begin{array}{l}\text { Glaurdić and Vuković (2017); } \\
\text { source of original data: State } \\
\text { Electoral Commission of the RC }\end{array}$ \\
\hline Mayor majority & $\begin{array}{l}\text { Proportion of deputies in the local } \\
\text { council supporting the mayor }\end{array}$ & $\begin{array}{l}\text { Glaurdić and Vuković (2017); } \\
\text { source of original data: State } \\
\text { Electoral Commission of the RC }\end{array}$ \\
\hline Unemployment & $\begin{array}{l}\text { Average monthly unemployment } \\
\text { rate }\end{array}$ & $\begin{array}{l}\text { Croatian Unemployment } \\
\text { Bureau: http://www.hzz.hr/ } \\
\text { default.aspx?id=10052 }\end{array}$ \\
\hline Income & $\begin{array}{l}\text { Income per capita (deflated to } 2010 \\
\text { levels), natural log transformed }\end{array}$ & $\begin{array}{l}\text { Croatian Bureau of Statistics: } \\
\text { https://www.dzs.hr/Hrv_Eng/ } \\
\text { publication/2014/SI-1526.pdf }\end{array}$ \\
\hline
\end{tabular}




\begin{tabular}{|c|c|c|}
\hline Variable & Description & Source \\
\hline Grants & $\begin{array}{l}\text { Per capita grants (deflated to } 2010 \\
\text { levels), natural log transformed }\end{array}$ & $\begin{array}{l}\text { Ministry of Finance: } \\
\text { http://www.mfin.hr/hr/lokalni- } \\
\text { proracun-arhiva }\end{array}$ \\
\hline Croats & $\begin{array}{l}\text { Proportion of population ethnically } \\
\text { Croatian }\end{array}$ & Croatian Bureau of Statistics \\
\hline Average age & $\begin{array}{l}\text { Average age for entire population } \\
\text { in municipality }\end{array}$ & Croatian Bureau of Statistics \\
\hline $\begin{array}{l}\text { Years of } \\
\text { education }\end{array}$ & $\begin{array}{l}\text { Average years of education for } \\
\text { population older than } 15 \text { years of age }\end{array}$ & Croatian Bureau of Statistics \\
\hline $\begin{array}{l}\text { War disabled } \\
\text { per } 1,000\end{array}$ & $\begin{array}{l}\text { Number of disabled persons whose } \\
\text { disability was caused by war }\end{array}$ & $\begin{array}{l}\text { Glaurdić and Vuković (2016); } \\
\text { source of original data: Croatian } \\
\text { Bureau of Statistics }\end{array}$ \\
\hline Settlement size & $\begin{array}{l}\text { Weighted average of settlement size } \\
\text { in a municipality as a measure of } \\
\text { urban-rural cleavage }\end{array}$ & $\begin{array}{l}\text { Glaurdić and Vuković (2016); } \\
\text { source of original data: Croatian } \\
\text { Bureau of Statistics }\end{array}$ \\
\hline Assembly size & $\begin{array}{l}\text { Total number of representatives } \\
\text { in the local assembly }\end{array}$ & $\begin{array}{l}\text { State Electoral Commission } \\
\text { of the RC }\end{array}$ \\
\hline
\end{tabular}




\section{REFERENCES}

1. Ansolabahere, S. and Snyder, J., 2002. The Incumbency Advantage in U.S. Elections: An Analysis of State and Federal Offices, 1942-2000. Election Law Journal: Rules, Politics, and Policy, 1(3), pp. 315-338.

2. Ateljević, J. and Budak, J., 2010. Corruption and public procurement: example from Croatia. Journal of Balkan and Near Eastern Studies, 12(4), pp. 375379. doi: 10.1080/19448953.2010.531202

3. Bađun, M., 2011. Odnos političke korupcije i javnih investicija - slučaj Hrvatske. Društvena istraživanja, 20(2), pp. 295-316.

4. Bandiera, O., Prat, A. and Valletti, T., 2009. Active and Passive Waste in Government Spending: Evidence from a Policy Experiment. American Economic Review, 99(4), pp. 1278-1308. doi: 10.1257/aer.99.4.1278

5. Bejaković, P., 2002. Corruption in Croatia: Institutional Settings and Practical Experiences. Politička misao, 39, pp. 128-155.

6. Besley, T., 2006. Principled Agents? The Political Economy of Good Government. New York: Oxford University Press.

7. Bićanić, I., 1997. Mjerenje veličine i promjena neslužbenog gospodarstva. Financijska praksa, 21(1-2), pp. 15-28.

8. Brennan, G. and Buchanan, J., 1980. The Power to Tax: Analytical Foundations of a Fiscal Constitution. Cambridge: Cambridge University Press.

9. Brollo, F. and Nannicini, T., 2012. Tying Your Enemy's Hands in Close Races: The Politics of Federal Transfers in Brazil. American Political Science Review, 106(4), pp. 742-761. doi: 10.1017/S0003055412000433

10. Budak, J. and Rajh, E., 2012. Corruption survey in Croatia: survey confidentiality and trust in institutions. Društvena istraživanja, 21(2), pp. 291-313.

11. Bueno de Mesquita, B. [et al.], 2002. Political Institutions, Policy Choices and the Survival of Leaders. British Journal of Political Science, 32(4), pp. 559590. doi: 10.1017/S0007123402000236

12. Bueno de Mesquita, B. [et al.], 2005. The Logic of Political Survival. Cambridge: MIT Press.

13. CBS, 2011. Popis stanovništva 2011. Zagreb: Croatian Bureau of Statistics.

14. CBS, 2013. Statistički ljetopis 2013. Zagreb: Croatian Bureau of Statistics.

15. Clarke, K. A. and Stone, R.W., 2008. Democracy and the Logic of Political Survival. American Political Science Review, 102(3), pp. 387-392. doi: 10.1017/S0003055408080131

16. European Commission, 2014. EU Anti-Corruption Report. Bruxelles. Available at: <http://ec.europa.eu/dgs/home-affairs/e-library/documents/policies/organized-crime-and-human-trafficking/corruption/docs/acr_2014_en.pdf>.

17. Faccio, M., 2006. Politically Connected Firms. American Economic Review, 96(1), pp. 369-386. doi: 10.1257/000282806776157704

18. Ferejohn, J., 1986. Incumbent Performance and Electoral Control. Public Choice, 50, pp. 5-25. doi: 10.1007/BF00124924 
19. Ferraz, C. and Finan, F., 2011. Electoral Accountability and Corruption: Evidence from the Audits of Local Governments. American Economic Review, 101(4), pp. 1274-1311. doi: 10.1257/aer.101.4.1274

20. Franičević, V., 1997. Temeljne značajke neslužbenog gospodarstva. Financijska praksa, 21(1-2), pp. 45-70.

21. Gallagher, M. E. and Hanson, J. K., 2015. Power Tool or Dull Blade? Selectorate Theory for Autocracies. Annual Review of Political Science, 18, pp. 367-385. doi: 10.1146/annurev-polisci-071213-041224

22. Gelman, A. and King, G., 1990. Estimating incumbency advantage without bias. American Journal of Political Science, 34(4), pp. 1142-1164. doi: $10.2307 / 2111475$

23. Glaurdić, J. and Vuković, V., 2016. Voting after war: Legacy of conflict and the economy as determinants of electoral support in Croatia. Electoral Studies, 42, pp. 135-145. doi: 10.1016/j.electstud.2016.02.012

24. Glaurdić, J. and Vuković, V., 2017. Granting votes: Exposing the political bias of intergovernmental grants using the within-between specification for panel data. Public Choice, 171(1), pp. 223-241. doi: 10.1007/s11127-017-0435-y

25. Grossman, G. M. and Helpman, E. 2002. Special Interest Politics. MIT Press, Cambridge, MA.

26. Hainmueller, J. 2012. Entropy Balancing for Causal Effects: A Multivariate Reweighting Method to Produce Balanced Samples in Observational Studies. Political Analysis, 20(1), pp. 25-46. doi: 10.1093/pan/mpr025

27. Hainmueller, J. and $\mathrm{Xu}, \mathrm{Y}$. 2013. Ebalance: A Stata Package for Entropy Balancing. Journal of Statistical Software, 54(7), August 2013.

28. HZZ, 2014. Employment bureau yearbook 2013, 2012, 2011, 2010, 2009. Zagreb: HZZ. Available at: <www.hzz.hr/default.aspx?id=10055>.

29. Ivanković, Ž. and Šonje, V., 2011. Nedemokratski kapitalizam i nova tranzicija. Prvi zagrebački ekonomski forum, Friedrich Ebert Stiftung, pp. 5-21.

30. Lee, D. S., 2008. Randomized experiments from non-random selection in US House elections. Journal of Econometrics, 142(2), pp. 675-697. doi: 10.1016/j. jeconom.2007.05.004

31. Mačkić, V., 2014. Political budget cycles at the municipal level in Croatia. Financial Theory and Practice, 38(1), pp. 1-35. doi: 10.3326/fintp.38.1.1

32. Madžarević-Šujster, S. and Mikulić, D., 2002. Procjena neslužbenog gospodarstva sustavom nacionalnih računa. Financijska teorija i praksa, 26(1), pp. 31-56.

33. McChesney, F., 1997. Money for Nothing: Politicians, Rent Extraction, and Political Extortion. Cambridge: Harvard University Press.

34. Ministarstvo financija Republike Hrvatske, 2014. Arhiva lokalnih proračuna 2009-2011. Available at: <http://www.mfin.hr/hr/lokalni-proracuni>.

35. North, D. C., Wallis, J. J. and Weingast, B.R., 2009. Violence and Social Orders. A Conceptual Framework for Interpreting Recorded Human History. Cambridge: Cambridge University Press. doi: 10.1017/CBO9780511575839 
36. Ott, K., 2002. Neslužbeno gospodarstvo u Republici Hrvatskoj 1990-2000. Financijska teorija i praksa, 26(1), pp. 1-30.

37. Persson, T. and Tabellini, G., 2000. Political Economics. Explaining Economic Policy. Cambridge: MIT Press.

38. Petrušić, Ž., 2015. Ustavni sud uvažio tužbu. Bandić je na slobodi, vraća se 15 milijuna kuna jamčevine! Jutarnji list, $9^{\text {th }}$ April 2015. Available at: <http:// www.jutarnji.hr/vijesti/hrvatska/ustavni-sud-uvazio-tuzbu-bandic-je-na-slobodi-vraca-se-15-milijuna-kuna-jamcevine/374065/>.

39. Reynal-Querol, M., 2002. Ethnicity, political systems, and civil wars. Journal of Conflict Resolution, 46(1), pp. 29-54. doi: 10.1177/0022002702046001003

40. Romić, T., 2016. Sabor usvojio 'lex Vlahušić', SDP i HNS već najavili: 'Zakon ćemo poslati na ocjenu ustavnosti. Večernji list, 15 ${ }^{\text {th }}$ December 2016. Available at: $<$ https://www.vecernji.hr/vijesti/sabor-usvojio-lex-vlahusic-sdpi-hns-vec-najavili-zakon-cemo-poslati-na-ocjenu-ustavnosti-1135966>.

41. Root, H. L. and Nellis, N., 2000. The Compulsion of Patronage: Political Sources of Information Asymmetry and Risk in Developing Country Economies In: B. Bueno de Mesquita and R. L. Hilton, eds. Governing for Prosperity. New Haven: Yale University Press.

42. Shleifer, A. and Vishny, R., 1994. Politicians and Firms. Quarterly Journal of Economics, 109, pp. 995-1925. doi: 10.2307/2118354

43. State Electoral Commission of the Republic of Croatia, 2014. Informacija o rezultatima izbora po županijama, 2009. i 2013. godina. Available at: $<$ http:// www.izbori.hr/izbori/izbori09.nsf/wi?openform for 2009> and $<$ http://www. izbori.hr/izbori/dip_ws.nsf/public/index?open\&id=DC9A\& for 2013>.

44. Štulhofer, A., 2004. Percepcija korupcije i erozija društvenog kapitala u Hrvatskoj 1995-2003. Politička misao, 41(3), pp. 156-169.

45. Tomičić, L., 2015. Biračima korupcija ne smeta: Zašto nikoga ne brinu pravomoćne presude kandidatima? Novi list, $15^{\text {th }}$ March 2015. Available at: $<$ http://www.novilist.hr/Vijesti/Hrvatska/Biracima-korupcija-ne-smeta-Zasto-nikoga-ne-brinu-pravomocne-presude-kandidatima>

46. Transparency International, 2016. Corruption by country: Croatia. Available at: <www.transparency.org/country\#HRV_PublicOpinion>.

47. Verdier, D., 1995. The politics of public aid to private industry: The role of policy networks. Comparative Political Studies, 28(1), pp. 3-42. doi: 10.1177/ 0010414095028001001

48. Vuković, V., 2017. Corruption and re-election. How much can politicians steal before getting punished? Doctoral dissertation, first paper. University of Oxford. 